\title{
Business Corporations and Stockholders' Rights Under the First Amendment
}

\author{
Victor Brudney†
}

Under American law, the business corporation has evolved from an entity that the state allowed to be created only as a special privilege, and even then rigidly restricted in size and powers, to one that the state enables to be formed freely with few limits on size or powers. ${ }^{1}$ That development has been accompanied by varying but persistent public apprehensions about the power of large aggregations of corporate capital. During the late nineteenth century, the growth of large publicly held corporations and their involvement in politics inflamed fears of "undue" political influence by such aggregated wealth. ${ }^{2}$ By the beginning of this century, public pressure resulted in regulatory restrictions on corporate political expenditures even if authority for such expenditures could be found within corporate charters. ${ }^{3}$

Until approximately World War II the received tradition of limited corporate power disfavored expenditure of funds for non-business purposes, including the use of funds to express corporate views on public or social affairs, whether or not such expression was designed to increase the corporation's wealth. ${ }^{4}$ Thereafter, although public fear of corporate politi-

$\dagger$ Weld Professor of Law, Harvard University

1. See Louis K. Liggett Co. v. Lee, 288 U.S. 517, 548-49 (1933) (Brandeis, J., dissenting); J. HURST, THE LEGITIMACY OF THE BUSINESS CORPORATION IN THE LAW OF THE UNITED STATES, 1780-1970, at 108-10 (1970).

2. See J. Shannon, MONEy and Politics 25-43 (1959); Lambert, Corporate Political Spending and Campaign Finance, 40 N.Y.U. L. REV. 1033, 1036 (1965). Such fears were not unknown at the beginning of the Republic. See 2 J. DAVIS, ESSAYS IN THE EARLIER HISTORY OF AMIERICAN CORPORATIONS 303-08 (1917); Ratner, The Government of Business Corporations: Critical Reflections on the Rule of "One Share, One Vote," 56 CORNELl L. REV. 1, 6 (1970).

3. Act of Feb. 1, 1870, ch. 11, 16 Stat. 63; Act of Jan. 26, 1907, ch. 420, 34 Stat. 864. See Bolton, Constitutional Limitations on Restricting Corporate and Union Political Speech, 22 ARIz. L. REV. 373, 375-79 (1980); Lambert, supra note 2, at 1035-37; Comment, Corporate Political Action Committees: Effect of the Federal Election Campaign Act Amendments of 1976, 26 CATH. U,L. REv. 756, 759 (1977). See also United States v. UAW, 352 U.S. 567, 570-76 (1957); United States v. CIO, 335 U.S. 106, 113 (1948); State v. Joe Must Go Club, Inc., 270 Wis. 108, 111, 70 N.W.2d 681, 682 (1955) (quoting La Follette message to Wisconsin legislature in 1905 urging ban on corporate political contributions).

4. See, e.g., Mobile Gas Co. v. Patterson, 293 F. 208, 226 (M.D. Ala. 1923), afTd in relevant part, 271 U.S. 131, 135 (1926) (campaign contributions improperly included in utility rate base); McConnell v. Combination Mining \& Milling Co., 31 Mont. 563, 571, 79 P. 248, 251 (1905) (directors cannot charge corporation for lobbying expenses); People ex rel. Perkins v. Moss, 187 N.Y. 410, 421-22, 80 N.E. 383, 386-87 (1907) (corporate political contribution ultra vires); Bolton, supra note 3, at 375-86. But cf. Schwartz v. Romnes, 495 F.2d 844 (2d Cir. 1974) (statute prohibiting corporate political payments not bar to contribution in support of or opposition to nonpartisan public referen- 
cal influence did not appear to lessen, and indeed, legislation tightened restrictions on corporate expenditures for such purposes, ${ }^{5}$ developing notions of corporate social responsibility altered the direction of corporation law, as well as the public position of corporate management and of many seeking to bridle corporate management. ${ }^{6}$ This movement led to authorization and encouragement of corporate participation in public affairs, including politics, in ways that are often only remotely connected with the corporation's profit-making function. ${ }^{7}$ Relying in part upon this growth in corporate participation in political and social discourse, the Supreme Court has restricted regulation of corporate political power, and indeed has fueled the growth of such power, by giving constitutional support to corporate freedom of speech. In a recent series of cases involving banks and public utilities, ${ }^{8}$ the Court has stated that the First Amendment protects political utterances by business corporations as such-whether or not they are engaged in the business of communication.

Regardless of whether increased corporate participation in the social and political life of the nation is desirable as a matter of policy, ${ }^{9}$ serious doubts exist regarding the validity of the constitutional support thus given to that movement. That support could significantly reduce the regulatory power of government over an institution whose existence is uniquely a function of government authorization, whose power and wealth often far exceed those of the government that created it, and that has long been a subject of pervasive government regulation. The logic and the policy on which such constitutionalization rests invite exploration of the validity of the teaching of those decisions.

dum); Marsili v. Pacific Gas \& Elec. Co., 51 Cal. App. 3d 313, 124 Cal. Rptr. 313 (1975) (expenditure by public utility on referendum permitted by both charter and law); M. HEALD, THE SOCINL RESPONSIBILITIES OF BUSINESS 234-42 (1970) (describing business involvement in religion and politics in 1950's). See also Peck v. Greyhound Corp., 97 F. Supp. 679 (S.D.N.Y. 1951) (not proper business purpose to discuss problem of societal racial segregation in proxy statement); SEC Rel. No. 34-3638 (Jan. 3, 1945) (matters of a "general political, social or economic nature" not properly included in proxy statements).

5. See J. Shannon, supra note 2, at 98; Bolton, supra note 3, at 402-11; Smith, Business, Bucks \& Bull: The Corporation, The First Amendment \& The Corrupt Practices Law, 4 DEL. J. CORP. L. 39, 44 n.26 (1978) (history of Federal Election Campaign Act of 1971 and post-Watergate amendments).

6. See Brudney, The Independent Director-Heavenly City or Potemkin Village? 95 HARV. L. REV. 597, 598-607 (1982).

7. The problems of corporate voluntarism have been the subject of an extensive literature. See Engel, An Approach to Corporate Social Responsibility, 32 STAN. L. REV. 1, 70 (1979). That the movement's implications would support, if not justify, managerial discretion in the use of corporate funds in politics has occasionally been a source of comment. See M. HEALD, supra note 4, at 237-42; Fletcher, Corporate Political Contributions, 29 BUS. LAW. 1071 (1974).

8. Consolidated Edison Co. v. Public Serv. Comm'n, 447 U.S. 530 (1980); First Nat'l Bank v. Bellotti, 435 U.S. 765 (1978); cf. Central Hudson Gas \& Elec. Corp. v. Public Serv. Comm'n, 447 U.S. 557 (1980); (protecting corporate commercial speech). See also Citizens Against Rent Control/ Coalition for Fair Housing v. City of Berkeley, 102 S. Ct. 434, 438 (1981).

9. See notes 6 \& 7 supra. 
That the wealth and power of large publicly held business corporations in the United States have a potent effect on both local and national politics no one would deny. ${ }^{10}$ The use of that wealth and power by corporate mangement to move government toward goals that management favors-with little or no formal consultation with investors-is also a phenomenon that is generally undeniable. ${ }^{11}$ Furthermore, there is good reason to believe that despite conflicts over particular issues, corporate managers, particularly of "big business," seek to move government policy in the same general direction, often independently of party affiliation, on many issues in areas such as taxes, military expenditures, allocating the costs of externalities, and a wide range of regulatory efforts. ${ }^{12}$ How much, or what proportion of, stock is held by investors who disagree with their mangement's political views is unknown. Doubtless the holders of the bulk of corporate stock do not disagree with most political positions for which their managements spend corporate funds, even when such expenditures are ultra vires. But the number of shareholders who are likely to disagree with some of management's political expenditures is not trivial, even if one takes into account only the present and potential interest of employees in pension funds and the more direct participants in the "people's capital-

10. See, e.g., IRS Administration of Tax Laws Relating to Lobbying, Part I: Hearings Before a Subcomm. of the Comm. on Government Operations, House of Representatives, 95th Cong., 2d Sess. 383 (1978) (business spends \$1 billion on grassroots lobbying annually) [hereinafter cited as IRS Hearings]; FED. TRADE COMM'N CONF., THE ECONOMICS OF FIRM SIZE, MARKET STRUCTURE AND SOCIAL PERFORMANCE 239-313 (J. Siegfried ed. July 1980) [hereinafter cited as FTC Report]; Vogel, The "New" Social Regulation in Historical and Comparative Perspective, in REgulation IN PERSPECTIVE 155 (McGraw, ed. 1981). See also H. ALEXANDER, FINANCING THE 1976 ELECTION 533619 (1979); A. HEARD, THE COSTS OF DEMOCRACY 104-17 (1962); S. LYDENBERG, BANKROLLING BAllots (1979); PARTIES, INTEREST GROUPS, \& CAMPAIGN FinANCE LnWs 9-25, 107-84 (M. Malbin ed. 1980); S. SETHI, ADVOCACY ADVERTISING AND LARGE CORPORATIONS (1977); J. SHANNON, supra note 2, at 13-63; Epstein, An Irony of Electoral Reform, REG., May/June 1979, at 35.

11. See C. Lindblom, Politics AND MARKeTs 192-97 (1977); Note, Corporate Political Affairs Programs, 70 YALE L.J. 821 (1961); cf. U.S. Chamber of Commerce, Business Response to the Powell Memorandum, WASHINGTON REPORT, Vol. 12, No. 24, Nov. 26, 1973 (recommending action by business firms to improve public opinion of American business).

12. See E. HERMin, CoRporate CONTROL, CoRPORATE POWER 162-86 (1981); C. LiNdbloM, supra note 11, at 170-200; cf. A. HEARD, supra note 10, at 104-11 (corporate gifts heavily favor Republicans); Adamany, PAC's and the Democratic Financing of Politics, 22 ARIZ. L. REV. 569, 595-96 (1980) (corporate PAC contributions disproportionately favor incumbents and Republicans); Wertheimer, The PAC Phenomenon in American Politics, 22 ARIZ. L. REV. 603, 610 (1980) (corporate $\mathrm{PAC}$ contributions favor incumbents first and Republicans second). But cf. Budde, Business Political Action Committees, in PARTIES, INTEREST GROUPS, AND CAMPAIGN FinanCE LawS, supra note 10, at 9, 16-21 (corporate PAC spending patterns are diverse); Mayton, Politics, Money, Coercion, and the Problem with Corporate PACs, 29 EMORY L.J. 375, 381 (1980) (corporate PACs usually nonideological and back incumbents); Wilson, Democracy and the Corporation, Wall St. J., Jan. 11, 1978, at 14, col. 4 (criticizing fears of corporate influence on politics). Of course, not all corporate executives see the same world; some prefer, in order either to benefit their firms or to satisfy their own personal preferences, governmental action that others oppose. See Chandler, The Adversaries, HARV. BUS. REV., Nov.-Dec. 1979, at 85-88; Reich, Why the U.S. Needs an Industrial Policy, HARV. BUS. REV., Jan.-Feb. 1982, at 74; Vogel, supra note 10. 
ism"; ${ }^{13}$ if we include the constituencies of those institutions, such as churches and universities, that are likely to believe that management should not have discretion to make such expenditures, the numbers are even larger. ${ }^{14}$ A government concerned with protecting First Amendment values could reasonably believe it important to free those citizens from bondage to management's political views, even if the bonds are seen as no more than restrictions on their investment opportunities. ${ }^{15}$

That concern appears to have been one stimulus to the legislative restrictions that the federal government and the states have imposed on corporate political activity. ${ }^{16}$ But those restrictions have been more or less narrowly aimed at political "contributions" in connection with the election of candidates to political office; ${ }^{17}$ they have not prohibited the varied corporate expenditures that, although not "contributions" to political candidates, effectively condition voters to accept or reject government policies or candidates. ${ }^{18}$ Examples of such expenditures include "issue" advertising or

13. See, e.g., P. DRUCKER, THE UNSEEN REVOLUTION 1-16 (1976) (pension funds of self-employed, public employees, and teachers own 10\% of all equities); Stern, \$2.9 Trillion in Pension Assets by 1995, PENSIONS \& INVESTMENTS 1, 3, 37 (1980) (In 1975, 48\% of all workers participated in private pension funds owning $\$ 103$ billion in equities, or $21.3 \%$ of corporate net worth). From 1970 to 1980 , employee stock ownership in pension funds increased both in absolute terms and proportionately. NEW YORK STOCK EXCHANGE, EXCHANGE INTERCHANGE, Vol. 3, No. 1, p. 3 (December 1981). See also E. HERMAN, supra note 12, at 138. ESOPs are still another form of employee stock participation that is growing. See ESOPS Tables: A Survey of Companies with Employee Stock Ownership Plans, $6 \mathrm{~J}$. CORP. L. 551 (1981). Of 30 million individual stockholders, $40 \%$ acquired stock through employee purchase plans. NEW YORK STOCK EXCHANGE, SHARE OWNERSHIP 1980, at i.

14 See E. HERMAN, supra note 12, at 138 (in 1978, charitable foundations and educational endowments owned common stocks listed on the New York Stock Exchange valued at $\$ 37$ billion).

15. See p. 270 infra.

16 To be sure, a primary stimulant to such legislation was the fear of the debauching influence of "the concerted use of money" by "artificial beings." See Uimed States v. United States Brewers' Ass'n, 239 F. 163, 168-69 (W.D. Pa. 1916). But both legislative history and contemporaneous opinion evince a hostility to directors' "use [of] stockholders' money for such purposes . . ." 40 CONG. REC. 96 (1905) (Roosevelt message to Congress urging ban on corporate political contributions). See, e.g., Hearings on Contributions to Political Committees before House Committee on the Election of the President, 59th Cong., 1st Sess. 76 (1905) (Williams testimony); Bolton, supra note 3, at 377-79 (assessing legislative importance of complaints about management's usurpation of stockholders' assets for political purposes the latter opposed). See also Cort v. Ash, 422 U.S. 66, 81-82 (1975); Note, Corporate Democracy and the Corporate Political Contribution, 61 IOWA L. REV. 545 (1975).

17. See Act of Jan. 26, 1907, ch. 420, 34 Stat. 864 (prohibiting corporate money contributions in connection with elections). Roosevelt had sought legislation prohibiting not merely corporate contributions to any political committee for any political purpose, but any use of funds "in connection with any legislation save by the employment of counsel in public manner for distinctly legal services." 40 CONG. REC. 96 (1905). There were attempts, in 1925 and in 1947, to extend the prohibition to contributions not merely of money but to other things of value, see Federal Corrupt Practices Act of 1925, ch. 368, 43 Stat. 1071, and to "expenditures," see Amendment to the Federal Corrupt Practices Act of 1925, ch. 120, 61 Stat. 159 (1947). But these laws did not effectively prevent expenditures by corporations other than those more or less plainly made for the benefit of candidates for office. See Bolton, supra note 3 , at 386-98.

18. See, e.g., IRS Hearings, supra note 10, at 35-42; Mastro, Costlow \& Sanchez, Taking the Initiative: Corporate Control of the Referendum Process Through Media Spending and What to Do About It, 32 FED. COM. L.J. 315 (1980) (heavy corporate spending on advertising defeated three initiatives in Colorado). See also Citizens Against Rent Control/Coaltion For Fair Housing v. City of 
"institutional" advertising, "grass roots" campaigns with respect to referenda or legislation, ${ }^{20}$ free use of company employees or facilities, and payments to outsiders to lobby or to campaign. ${ }^{21}$ Corporations using such lawful means of generating support for or opposition to government policies and candidates ${ }^{22}$ have spent sums large enough to raise significant questions about the use of stockholders' funds to support political views that many stockholders do not favor. ${ }^{23}$

The constitutional distinction drawn in Buckley v. Valeo between "contributions," which create the possibility or appearance of corruption, and "expenditures," which it is said do not, ${ }^{24}$ may be valid for strictures on individual human beings. But the distinction does not address the problem of defining the appropriate relationship between corporate political power, which the nation has historically feared, ${ }^{25}$ and stockholders' individual political preferences. In any event, whether corporate management may harness the funds of individual investors to further political or social goals the latter do not support should not depend upon a distinction between corporate contributions and corporate expenditures. In either case, unless inves-

Berkeley, 102 S. Ct. 434, 442-43 (1981) (White, J., dissenting).

19. See E. BARNOUW, THE SPONSOR 77-151 (1978) (discussing use of electronic media to promote corporate views); E. HeRMAN, supra note 12, at 406 n.100; Schaefer, The First Amendment, Media Conglomerates and "Business" Corporations: Can Corporations Safely Involve Themselves in the Political Process? 55 ST. JOHNS L. REV. 1, 28-29 (1980) (unclear when issue advertising violates corrupt practices legislation); Comment, Corporate Advocacy Advertising: When Business' Right to Speak Threatens the Administration of Justice, 1979 DET. C.L. REV. 623, 623-27 (describing corporate advocacy advertising).

20. See Citizens Against Rent Control/Coalition for Fair Housing v. City of Berkeley, 102 S. Ct. 434 (1981); Cammarano v. United States, 358 U.S. 498 (1959); Cooper, The Tax Treatment of Business Grassroots Lobbying: Defining and Attaining the Public Policy Objectives, 68 ColUM. L. REV. 801 (1968).

21. See Lambert, supra note 2, at 1052-59; DIvision of CORPORATE FINANCE, SEC, 96TH CONG., 2D SESS., STAFF REPORT ON CORPORATE ACCOUNTABILITY 199-200 (1980) (printed for Senate Comm. on Banking, Housing, and Urban Affairs) [hereinafter cited as SEC REPORT].

22 See Bolton, supra note 3, at 411-12; Note, supra note 11, at 822-27; Note, supra note 16, at 558-79.

23. See G. Thayer, Who ShaKeS THE MONEY TREe? 108-22 (1973); note 10 supra.

24. 424 U.S. 1, 14, 26 (1976). But see Comment, Independent Political Committees and the Federal Election Laws, 129 U. PA. L. Rev. 955 (1981) (permissibility of contributions to "parallel campaigns" may undermine effectiveness of federal limits on direct contributions to candidates). The distinction between ballot or referenda issues and election to office that the Court made in First Nat'l Bank v. Bellotti, 435 U.S. 765, 788 n.26 (1978), relates in some measure to the difference between "contributions" and "expenditures." See Citizens Against Rent Control/Coalition for Fair Housing v. City of Berkeley, 102 S. Ct. 434, 438-39 (1981) ("contributions" supporting or opposing referenda are constitutionally protected because they do not threaten corruption of candidates); California Medical Ass'n v. FEC, 101 S. Ct. 2712 (1981); Schwartz v. Romnes, 495 F.2d 844 (2d Cir. 1974); FEC v. National Right to Work Comm., 501 F. Supp. 422 (D.D.C. 1980); FEC v. Weinsten, 462 F. Supp. 243 (S.D.N.Y. 1978).

25. See Schwartz v. Romnes, 357 F. Supp. 30 (S.D.N.Y. 1973), rev'd, 495 F.2d 844 (2d Cir. 1974) (discussing range of behavior state prohibitions against corporate "political" contributions seek to interdict); Fletcher, Corporate Political Contributions, 29 BUS. LAlw. 1071, 1073 (1974); Lambert, supra note 2, at 1035-38. 
tor approval is obtained, the funds of some investors are being used to support views they do not favor.

The Court's recent opinions cast doubt on the legality of existing strictures on corporate "contributions"26 as well as on future efforts to protect individual investors from having to yield their assets to managerial or majoritarian decisions on all the other political activities in which their corporations engage. ${ }^{27}$ The opinions are cast in terms of protecting the process of speech or the exchange of communications; the holdings rest on the notions that, given protected expression, "speakers" cannot generally be hindered in uttering such expression, and that corporations are such "speakers."28

The last proposition is not self-evident. Corporations are accorded "personality" in order to create a mechanism for saving transaction costs in business dealings, not to create autonomous beings. Accordingly, they may be deemed legal "persons" separate from their stockholders for many constitutional purposes, particularly when corporate dealings with third persons involve contract rights, ownership of property, or liability for injuries. ${ }^{29}$ Moreover, corporations that are in the business of communicating have special ground for claiming protection under the First Amendment. ${ }^{30}$ But corporations have not been treated as "persons" for all constitutional purposes. ${ }^{31}$ Indeed, the First Amendment lacks any reference to "person." And none of the cases invoking it as a shield for the entity's "speech" involved the relationship of "its" speech to its individual investors' freedom of speech. Hence, none has addressed the question of the scope of the government's discretion, when authorizing the creation or regulating the

26. See Citizens Against Rent Control/Coalition for Fair Housing v. City of Berkeley, 102 S. Ct. 434, 438-39 (1981).

27. See Central Hudson Gas \& Elec. Corp. v. Public Serv. Comm'n, 447 U.S. 557, 561-62 (1981) (desirable to open "channels of communication"); First Nat'l Bank v. Bellotti, 435 U.S. 765, 783 (commercial speech promotes "free flow of commercial information").

28. See Consolidated Edison v. Public Serv. Comm'n, 447 U.S. 530, 533 (1980) (the "inherent worth of the speech in terms of its capacity for informing the public does not depend upon the identity of its source, whether corporation, association, union or individual"); First Nat'l Bank v. Bellotti, 435 U.S. 765, 784-86 (1978) ("speech that otherwise would be within the protection of the First Amendment [does not lose] that protection simply because its source is a corporation"); note 62 infra.

29. See New York Times Co. v. Sullivan, 376 U.S. 254 (1964) (liability for libel); Wheeling Steel Corp. v. Glander, 337 U.S. 562 (1949) (property); Santa Clara County v. Southern Pac. R.R., 118 U.S. 394 (1886) (same); Graham, The "Conspiracy Theory" of the Fourteenth Amendment, 47 YALE L.J. 371 (1938). But cf. Bell v. Maryland, 378 U.S. 226, 245-46 (1964) (Douglas, J., concurring) (corporate interest in enforcing its "personal prejudices" not constitutionally protected).

30. See, e.g., Kingsley Int'I Pictures Corp. v. Regents, 360 U.S. 684 (1959); Joseph Burstyn, Inc. v. Wilson, 343 U.S. 495 (1952); Pennekamp v. Florida, 328 U.S. 331 (1946); Grosjean v. American Press Co., 297 U.S. 233 (1936); O'Kelley, Constitutional Rights of Corporations Revisited: Social and Political Expression and the Corporation After First National Bank v. Bellotti, 67 GEO. L.J. 1347, 1359-66 (1979).

31. See, e.g., Hale v. Henkel, 201 U.S. 43, 75 (1906) (no privilege against self-incrimination for corporations); cf. Bank of Augusta v. Earle, 38 U.S. (13 Pet.) 519, 586-87 (1839) (foreign corporation cannot claim rights of a person under privileges and immunities clause). 
operation of a business corporation, to allocate the corporation's capacity to become a "speaker" in a manner that appropriately accommodates the rights of the individual participants.

To answer that question requires a preliminary observation concerning government power to regulate the internal affairs of corporations, which do not exist without the government's authorization. ${ }^{32}$ Normally the allocation of authority among stockholders, or between stockholders and managers, to expend corporate funds is a function of state law, and on occasion also of federal law. Among the configurations that government might allow for the allocation of such authority are (1) complete contractual freedom for the participating investors to make their own arrangements, (2) restriction of the participants to a prescribed statutory or common-law scheme for the allocation of such powers, or (3) restriction to such a prescribed scheme coupled with permission for the participants to alter that allocation, to a limited degree, by their contract. ${ }^{33}$ While other provisions of the Constitution may limit the government's power to prescribe the allocation of decisionmaking authority, the restrictions on government power contained in the First Amendment do not address, or without more inhibit, the government's power to determine whether corporate decisions should be made by officers or directors without even consulting stockholders, only by stockholders, or only by supermajority or unanimous vote of stockholders.

32. To recognize the corporation as a set of contractual arrangements by which individuals effect, more efficiently than would the market, collective economic purposes does not preclude treatment of the corporation as an entity for many purposes. But in order thus to function as an institution that implements the aspirations of its participants, the enterprise imperatively requires the government to foster-and tolerate-it. Yet it is currently fashionable to dispute the notion that the corporation exists by sufferance of the state, and that it is therefore subject to many restrictions that the state could not impose on an individual. See Hessen, $A$ New Concept of Corporations: $A$ Contractual and Private Property Model, 30 Hastings L.J. 1327 (1979). The argument that the right to incorporate is a "natural" contractual right of individuals has little support in history and none in logic. As a matter of policy, society has an interest in regulating the formation and activities of private groups, even for activities the First Amendment protects, to an extent that is not, and should not be, permitted with respect to individuals acting separately. This interest is particularly acute with respect to corporations, if only because of their indefinite existence and limitless size and power. In any event, the internal allocation of power or votes of individual members with respect to group decisions cannot be solely a matter of contract if minorities are to be protected from majorities over the life of the enterprise. Without external mandates to limit majoritarian power, corporate contractual arrangements would presumably be so wasteful that investors would want, and government would rationally seek, to impose them. See Anderson, Conflicts of Interest: Efficiency, Fairness and Corporate Structure, 25 U.C.L.A. L. REV. 738 (1978).

33. See, e.g., Providence and Worcester Co. v. Baker, 378 A.2d 121 (Del. 1977); Lehrman v. Cohen, 43 Del. Ch. 222, 222 A.2d 800 (1966); Ellingwood v. WolPs Head Oil Refining Co., 27 Del. Ch. 411, 38 A.2d 743 (1944); Stroh v. Blackhawk Holding Corp., 48 Ill.2d 471, 272 N.E.2d 1 (1971). The notion that state statutory and common law should restrict the parties' freedom of contract in the interest of protecting minority stockholders against majority use of the minority's assets for purposes alien to the latter's interest in the common venture is a continuous theme of corporate law. See, e.g., Singer v. Magnavox Co., 380 A.2d 969 (Del. 1977); Recent Developments in Delaware Corporate Law, 3 DEL. J. CORP. LAW 19 (1977). 
More particularly, until First National Bank of Boston v. Bellotti, ${ }^{34}$ nothing in the Constitution was thought to restrict the state's power to forbid management from wasting corporate assets. In that case, however, in language that went much further than the facts required,,$^{35}$ the Court stated that the First Amendment protects corporate speech even if it does not materially affect the corporation's business, and that the corporate character of the "speaker" does not legitimize government restrictions on "its" wasteful speech. On those premises, the Court held unconstitutional a statute drawn to forbid corporate expenditures opposing a referendum on a graduated income tax, even though the Massachusetts legislature found and the Massachusetts Supreme Judicial Court concluded that the tax question submitted in the referendum did not materially affect the property, business, or assets of the corporate litigants. ${ }^{36}$

To be sure, there is considerable room for argument over whether any particular corporate expenditure is "waste." But, as the Supreme Court acknowledged in the Bellotti case, management might be required to account to stockholders in a derivative suit for the expenditures there involved. ${ }^{37}$ Yet, notwithstanding the state's power thus to authorize sanctions against management after the expenditure is made, the Court stated that the First Amendment denies the state the power to prohibit the expenditure directly by statute. It is hard to see any distinction of constitutional dimension between forbidding a corporation from engaging in certain behavior under penalty of criminal punishment for management, and permitting the threat of stockholder derivative suit against, or ouster of, management ${ }^{38}$ to deter such behavior-unless the concept of prior re-

34. 435 U.S. 765 (1978).

35. The Court's opinion alluded to several considerably narrower grounds for its holding: that the interdicted speech was not waste, see note $70 \mathrm{infra}$, that the statute was really aimed not at waste, but at speech, see 435 U.S. at 793, that the statute was aimed only at speech with a particular content, for which no justification was offered under the equal protection clause, see id., or that the statute totally suppressed speech, see note 109 infra. The unnecessary breadth of the opinion, if not the holding, in Bellotti may have been influenced by the views its author held prior to his appointment to the Court. See Powell, Confidential Memorandum: Attack on American Free Enterprise System, WaSHINGTON REP. SUPP., Vol. 12, no. 24, Aug. 23, 1971 (proposing an aggressive national campaign of corporate expenditures to influence public opinion in favor of American business) (hereinafter cited as Powcll Memorandum].

36. First Nat'l Bank v. Attorney Gen., 371 Mass. 773, 785-87, 359 N.E.2d 1262, 1270-71 (1977), rev'd sub nom. First Nat'l Bank v. Bellotti, 435 U.S. 765 (1978).

37. 435 U.S. at 795 .

38. If the government has power to prescribe rules to which the participants in the group must adhere in allocating authority to act for the group, it can also prescribe remedies for violation of those rules. The state is not restricted to limiting such remedies to stockholders' derivative suits or to stockholders' votes to oust management. Nothing in the Constitution forbids the state from imposing other civil costs or penalties on management for such managerial behavior. Cf. DEL. CORP. LAW § 124 (1974) (allowing restitution in suits for ultra vires activity); N.Y. BUS. CORP. LAW. $\$ 203$ (Consol. 1963) (same). 
straint is relevant. ${ }^{39}$ But if that concept is applicable, its invocation invites inquiry into the extent to which the state may regulate corporate behavior in deference to differences of opinion among corporate stockholders.

That question implicates, inter alia, the questions (1) whether the First Amendment restricts the government's power to say who "in" the corporation is authorized to spend corporate money when the corporation engages in speech in violation of its charter, (2) whether, if state law generally permits management to make expenditure decisions, the government can condition expenditures for corporate political or noncommercial speech in matters that would otherwise be within the authority of management on the consent of stockholders, and thus effectively prohibit such speech, and (3) whether the government can authorize management to make some kinds of corporate speech, such as commercial speech, but not others, such as political or noncommercial speech, without the approval or express consent of stockholders.

\section{Ultra Vires Speech: Waste}

To start with the least complicated configuration, let us assume that state common law or statutory law forbids waste by corporate management, and that it defines waste as expenditures from which the enterprise cannot reasonably be expected to benefit. Let us assume further a corporation engaged in, and by its charter confined to, the manufacture of massproduced plastic toys. The corporation uses unskilled labor, principally ethnic minorities and women, who are available at the lowest permissible wages. The president of the company is personally hostile to minorities and believes that a woman's place is in the home. He also favors the election as Senator of Mr. $X$, who seeks a constitutional amendment repealing the equal protection clause, repeal of equal rights legislation, and enactment of state legislation restricting the employment of women and minorities. The president proposes to spend corporate funds in support of $\mathrm{Mr} . X$ and his policies. If those policies prevail, the president can then satisfy his personal preference against hiring women and minorities, even though doing so not only will fail to benefit the corporation, but will deprive it of a supply of cheap labor that will continue to be available to competitors in other states.

39. Management's fear-ex ante-of acting wastefully results from the same uncertainty concerning the "materiality" of the expenditure regardless of whether the threatened sanction is penal or civil. Moreover, prior restraint contingent upon government license or approval, or based on judicial injunction against proposed speech, implicates different considerations from those involved when the prior "restraint" merely requires consultation between agent and principal in order to determine whether the principal will authorize the agent to speak or will seek to enjoin the agent from speaking. 


\section{A. Prohibitions on All Forms of Corporate Waste}

Under venerable doctrine, expenditure of corporate funds that constitutes waste cannot be made lawfully without the consent of all the stockholders; any officers or directors who authorize or make wasteful expenditures are accountable to stockholders who object, even if those who object are only a small minority. ${ }^{40}$ The fact that the wasteful behavior takes the form of political speech not reasonably related to the corporation's business does not make management's usurpation of corporate funds for that purpose any less wasteful. Indeed, as noted, the Bellotti decision explicitly acknowledges that the president can be made accountable to stockholders for wasteful speech, apparently no less than for any other behavior that violates a general prohibition against waste. ${ }^{41}$

The logic of that conclusion is unassailable; but it bears some elaboration since it implies that the First Amendment permits effective, if not formal, government prohibition of wasteful corporate speech as part of a general prohibition against corporate waste. Judicial scrutiny of such a state law, at least if the law is not invoked discriminatorily, should not be any stricter than judicial review of a law forbidding any other form of waste or improper diversion. Although the First Amendment protects the president's right to express himself, it does not require that the state refrain from prohibiting him from stealing in order to obtain the funds to enable him to exercise that right. Nor does the First Amendment inhibit the state from obstructing his exercise of that right by denying him the opportunity to do so with other people's money, ${ }^{42}$ or, more particularly, by denying him the use of corporate funds to cause the corporation to speak for him. ${ }^{43}$ So long as the government's mandate is part of a general prohi-

40. See, e.g., Rogers v. Hill, 289 U.S. 582, 591 (1933); Adams v. Smith, 275 Ala. 142, 153 S.2d 221 (1963); Schreiber v. Bryan, 396 A.2d 512, 518 (Del. Ch. 1978); Saxe v. Brady, 40 Del. Ch. 474, 184 A.2d 602 (1962); Kerbs v. California E. Airways, Inc., 33 Del. Ch. 69, 90 A.2d 652 (1952); Rosenfeld v. Fairchild Engine \& Airplane Corp., 309 N.Y. 168, 180-81, 128 N.E.2d 291, 297 (1955) (Van Voorhis, J., dissenting). At common law, a requirement of unanimous consent of shareholders was not unknown. It "was required for such extraordinary corporate action as the sale of the assets of a prosperous corporation, a merger, or consolidation, or an amendment changing the business or altering the rights or preferences of shareholders." R. STEVENS, HANDBOOK ON THE LAW OF PRIVATE CORPORATIONS 566 (2d ed. 1949) (footnote omitted). The unanimous consent of a class of investors is required in order to alter some of the terms of their contract under the "absolute priority" doctrine. See Case v. Los Angeles Lumber Prod. Co., 308 U.S. 106 (1939); Trust Indenture Act of 1939, 15 U.S.C. $\$ 77 \mathrm{ppp}(\mathrm{b})$ (1976) ( $\$ 316(\mathrm{~b}))$. But cf. Bankruptcy Act of 1978, 11 U.S.C. $\S 1126$ (Supp. III 1979) (narrowing absolute priority doctrine).

41. See 435 U.S. at 795. See also Cort v. Ash, 422 U.S. 66, 84 (1975).

42. The same analysis applies to use of corporate funds by majority stockholders to cause the corporation to finance speech not related to corporate business.

43. Even if he has a right to spend on speech stolen funds that he has reduced to his possession, cf. New York Times Co. v. United States, 403 U.S. 713 (1971) (prior restraint on publication of stolen documents unlawful), he does not have a right to compel the owner of the funds to support his speech by expending those funds on his behalf. 
bition against waste that is applied evenhandedly, its propriety as a restriction on the president is no less valid when applied to wasteful speech made to further his personal views than when applied to any other abuse of corporate assets by the president, like the purchase of a house for his children or the violation of the labor laws to satisfy his personal preferences. ${ }^{44}$

Neither the public's interest in free speech nor the listener's interest in receiving messages on "all matters of public concern"45 alter this result. In the Bellotti opinion, however, Justice Powell invoked the analysis offered in the commercial speech cases, ${ }^{46}$ and rejected the state's attempt to rely solely on its authority to restrict the powers of the corporate speaker. ${ }^{47}$ Instead, he insisted that the issue is whether the First Amendment protects the "expression" from abridgement. In focusing analysis on the expression, he appears to have been concerned with protecting the audience's interest in receiving communications and the general public's interest in the free interchange of information, ideas, and opinions. ${ }^{48}$ The state's effort to protect investors against management's spending funds in ways the corporate charter does not authorize, or indeed forbids, could not thwart that "societal" interest. ${ }^{49}$

But if the First Amendment protects the "expression" from abridgement, it assumes that there is an expression. If there is a right to be informed, it is only the right to hear or to receive what others can and wish to express. Listeners do not themselves generate the speech that the First Amendment protects, nor can they be enriched by it, unless willing and able speakers exist. To be sure, the audience's right to receive prohibits the government, at least without justification meeting First Amendment standards, from forbidding or impeding the conveyance of a message that a speaker is able, and wishes, to utter; $;^{50}$ that right may even give a wouldbe speaker standing to litigate the audience's rights, ${ }^{51}$ or give the audience

44. Cr. Abrams v. Allen, 297 N.Y. 52, 74 N.E.2d 305 (1947) (plant closing in order to punish employees and vent personal prejudice may constitute waste).

45. Thornhill v. Alabama, 310 U.S. 88, 101-02 (1940).

46 See, e.g., Virginia State Bd. of Pharmacy v. Virginia Citizens Consumer Council, 425 U.S. 748 (1976).

47. See 435 U.S. at 777 ; note 28 supra.

48. 435 U.S. at 777.

49. Id. at 785 .

50. See, e.g., Red Lion Broadcasting Co. v. FCC, 395 U.S. 367 (1969); Lamont v. Postmaster Gen., 381 U.S. 301 (1965); Meyer v. Nebraska, 262 U.S. 390 (1923); cf. Stanley v. Georgia, 394 U.S. 557 (1969) (right to receive ideas precludes government from punishing private possession of obscene materials). But cf. Snepp v. United States, 444 U.S. 507 (1980) (secrecy restrictions in former CIA employee's employment contract enforceable); Kleindienst v. Mandel, 408 U.S. 753 (1972) (Congress may empower Attorney General to deny temporary visa to Marxist theoretician despite First Amendment interests of those who wish to communicate with him).

51. See Marsh v. Alabama, 326 U.S. 501 (1946); Smith, supra note 5, at 83. 
standing to litigate the speaker's rights. ${ }^{52}$ But the audience does not have a right to compel others to furnish information or expression, ${ }^{53}$ to require others to subsidize its distribution, ${ }^{54}$ or to require the government to subsidize $\mathrm{it}^{55}$ or to generate and distribute it. ${ }^{56}$

52. See, e.g., Virginia State Bd. of Pharmacy v. Virginia Citizens Consumer Council, 425 U.S. 748 (1976); cf. Lamont v. Postmaster Gen., 381 U.S. 301, $307-08$ (1965) (Brennan, J., concurring) (First Amendment protects right to receive publications). See generally United States v. Chestnut, 394 F.Supp. 581, 588-89 (S.D.N.Y. 1975), aff'd, 533 F.2d 40 (2d Cir.), cert. denied, 429 U.S. 829 (1976).

53. The government may protect an unwilling recipient by precluding a speaker from privately pressing "even 'good' ideas" on him through the mails. See Rowan v. United States Post Office Dept., 397 U.S. 728, 738 (1970); cf. Martin v. Gity of Struthers, 319 U.S. 141, 148 (1943) (dicta) (government may punish those who solicit at homes of others contrary to latter's previously expressed will). But cf. Consolidated Edison Co. v. Public Serv. Comm'n, 447 U.S. 530, 542 (1980) (customers may avoid exposure to objectionable material in billing envelopes by discarding it). This principle would equally validate state efforts to protect an unwilling speaker from being made to support messages that others wish to hear.

It does not seriously detract from this conclusion that the disclosure of sources may be compelled in litigation, see Branzburg v. Hayes, 408 U.S. 665 (1972), that government may permit speech in public places despite the presence of unwilling recipients, see Public Util. Comm'n v. Pollack, 343 U.S. 451,465 (1952), that the interest of willing recipients in company towns is brigaded with the willingness of speakers to speak as a justification for striking down prohibitions on the latter's speech, see Marsh v. Alabama, 326 U.S. 501, 505 (1946); Martin v. City of Struthers, 319 U.S. 141 (1943); Note, Listeners' Rights Providing a State Action Theory in the "Company Town" Analogues, 55 IND. L.J. 91 (1979), or that the public may be entitled to collect otherwise accessible information and assemble a mosaic, see United States v. Progressive, Inc., 467 F. Supp. 990 (W.D. Wis.), appeal dismissed, 610 F.2d 819 (7th Cir. 1979).

54. See Miami Herald Publishing Co. v. Tornillo, 418 U.S. 241 (1974); CBS v. Democratic Nat'l Comm., 412 U.S. 94, 124 (1973); cf. Consolidated Edison Co. v. Public Serv. Comm'n, 447 U.S. 530, 555 (1980) (Blackmun, J., dissenting) (government may prevent ratepayers from being forced to subsidize public utility's bill inserts discussing controversial issues). Whether the First Amendment permits government to force an owner of property to make that property available to others for expression of their views appears to turn on whether the property constitutes a "public" locus of speech or a licensed medium of communications. See, e.g., United States Postal Serv. v. Council of Greenburgh Civic Ass'ns, 101 S. Ct. 2676 (1981) (letter box not public forum); Pruneyard Shopping Center v. Robins, 447 U.S. 74 (1980) (state may require private shopping center to permit individuals to exercise free speech rights on premises). See also Hudgens v. NLRB, 424 U.S. 507 (1976); Lloyd Corp. v. Tanner, 407 U.S. 551 (1972); Red Lion Broadcasting Co. v. FCC, 395 U.S. 367 (1969); Marsh v. Alabama, 326 U.S. 501 (1946). Cases that have found a public locus of expression or a licensed medium of communication to exist have found that the rights of the property owner are not violated so long as he is not visibly associated with the views of those to whom the property was made available and he is well able, in the same medium, to oppose such views. In Red Lion the government asserted the audience's entitlement not in order to force a private person to support speech with which he disagreed, but to force the government's licensee to supply the licensed medium to views that a third person was willing to utter, given that the licensee had made the medium available to contrary views. See generally T. EMERSON, THE SYSTEM OF FREEDOM OF EXPRESSION 645-71 (1970); L. TRIBE, AMERICAN CONSTITUTIONAL LAW 693-700 (1978); Schauer, Hudgens v. NLRB and the Problem of State Action in First Amendment Adjudication, 61 MiNN. L. REV. 433 (1977).

55. See Greer v. Spock, 424 U.S. 828 (1976); Lehman v. City of Shaker Heights, 418 U.S. 298 (1974). If the government does subsidize speech, problems arise with respect to equal access to the subsidy. See Southeastern Promotions, Ltd. v. Conrad, 420 U.S. 546 (1975). See also Karst, Equality as a Central Principle in the First Amendment, 43 U. CHI. L. REV. 20, 43-52 (1975).

56. To say that the government need not generate information does not mean that it is never obliged to distribute information that it possesses. It is not inconsistent with the proposition that the right to receive communication is conditioned on the existence of willing and able private speakers that the public may be entitled to information in government files that is relevant to "public" purposes and exercise of the suffrage. See BeVier, An Informed Public, An Informing Press: The Search for a Constitutional Principle, 68 CALIF. L. REV. 482 (1980). Moreover, if the government has been given 
Certainly, to the extent that the government impedes a speaker from making a communication, it narrows the listener's opportunity to receive it and the community's opportunity for "the discovery and spread of political truth." ${ }^{17}$ Accordingly, although the Supreme Court appears to be less than committed to this view, ${ }^{58}$ under the First Amendment courts must test the validity of an impediment to expression by its consequences to listeners and to the public as well as to the speaker. But it does not follow that the public is entitled to the exchange of information, or that listeners can compel its distribution to them, if speakers do not wish, or are economically or organizationally unable, to make such communications. In short, contrary to Justice Powell's implication, ${ }^{59}$ the interests of the listener and the public in the exchange or circulation of views are cumulative upon, but not independent of, a speaker's ability and desire to speak. ${ }^{60}$

Moreover, the government is not obliged to make all organizations whose form it authorizes or whose existence it licenses able to utter communications that some of the organization's members oppose or that are on matters beyond the organization's charter powers. $A$ 's right to receive information does not require the state to permit $B$ to steal from $C$ the funds that alone will enable $B$ to make the communication. For the state to condition the association of $B$ and $C$ in a commercial venture upon their joint consent to every act of joint communication that constitutes waste is no more significant a curtailment of $A$ 's right to receive such communication. If the state's laws prohibiting violation of the participants' agreement concerning what the collective can say or their rules determining how the collective shall decide to speak can thus legitimately restrict

information, the audience may, in some circumstances, have a right to receive it in spite of the supplier's desire not to have it disclosed. See, e.g., Richmond Newspapers, Inc. v. Virginia, 448 U.S. 555 (1980) (proceedings in courtroom); Emerson, Legal Foundations of the Right to Know, 1976 WASH. U.L.Q. 1, 14.

57. Whitney v. California, 274 U.S. 357, 375 (1927) (Brandeis, J., concurring).

58. See Kleindienst v. Mandel, 408 U.S. 753 (1972).

59. See note 28 supra.

60. Justice Blackmun initiated his discussion of listeners' rights under the First Amendment in Virginia State Bd. of Pharmacy v. Virginia Citizens Consumer Council, 425 U.S. 748 (1976), with the observation that "[f]reedom of speech presupposes a willing speaker." Id. at 756. See Baker, Commercial Speech: A Problem in the Theory of Freedom, 62 Iowa L. REv. 1, 3 (1976); Baker, Scope of the First Amendment Freedom of Speech, 25 U.C.L.A. L. REV. 964, 1006-07 (1978). While Lamont v. Postmaster Gen., 381 U.S. 301 (1965), involving a foreign speaker, suggests that the recipient's entitlement is not dependent upon the speaker's "right" to speak, the recipient's "right" only matured because there existed a speaker willing and able (apart from government prohibition) to speak. Cf. Procunier v. Martinez, 416 U.S. 396, $408-09$ (1974) (improper censorship violates First Amendment rights of recipients of inmates' letters); New York Times Co. v. United States, 403 U.S. 713 (1971) (suggesting public interest in disclosure may excuse Times for disclosing information illegally obtained even if it does not excuse Times for illegally acquiring that information); Martin v. City of Struthers, 319 U.S. 141, (1943) (ban on door-to-door distribution of literature violates speech rights of distributor and potential receivers). See also Landmark Communications, Inc. v. Virginia, 435 U.S. 829 (1978); Nebraska Press Ass'n v. Stuart, 427 U.S. 539 (1976). 
the act of joint expression, nothing in the right to be informed invalidates those restrictions. By the same token, the public interest in any such interchange and in the fruits that such interchange may produce rises no higher than the corporate power, under the terms of the corporation's charter, to utter the information. ${ }^{61}$

If that analysis permits the state thus to forbid the president from causing the corporation to make wasteful expenditures equally whether the waste is communication or other behavior, what justification did the Court urge for striking down the Massachusetts statute in Bellotti? At the heart of the decision appears to be the Court's perception that the statute interdicted "the corporation's" behavior rather than the behavior of the human beings causing the corporation to act. ${ }^{62}$ But to reify the corporation, to accept the notion that the corporation is a person and that the First Amendment protects "its" speech, does not end the matter. Rather, it leaves to be solved the crucial questions of the state's power to decide who, within the corporation, may authorize it to utter that speech, ${ }^{63}$ and whether in light of the answer to that question, at least some corporate utterances, even on purely political matters, are not "protected speech."

61. The Court's statement that "Consolidated Edison's position as a regulated monopoly does not decrease the informative value of its opinions on critical public matters," Consolidated Edison Ca. v. Public Serv. Comm'n, 447 U.S. 530, 534 n.1 (1980), is thus insufficient to require Con Ed to utter such opinions. Whether, because of the monopoly it grants to Con Ed, the state may condition that company's communications to its captive audience on clearance with the Public Utilities Commission raises a different question. The answer does not turn on the public's "entitlement" to that information unless Con Ed, through its internal decisionmaking apparatus, wishes to communicate it.

62. Thus the Court emphasized that a long line of its decisions precludes the state from infringing the "protected speech" of "corporate bodies," 435 U.S. at 778 n.14, and that its decisions preclude legislatures from "dictating the subjects about which persons may speak and the speakers who may address a public issue," id. at 785. Indeed, the Court suggested that a significant defect in the statute was that it would prohibit the corporation from speaking "even if its shareholders unanimously authorized" the speech. Id. at 794. Compare Pipefitters Local 562 v. United States, 407 U.S. 385, 416 n.28 (1972) (suggesting that unanimous vote might legitimate union political expenditures) with United States v. Lewis Food Co., 366 F.2d 710, 713-14 (9th Cir. 1966) (suggesting that ban on such contributions violated even if unanimous stockholder consent obtained).

63. The courts and the bar have long recognized the divergence among the interests of the corporate "entity," its managers, its directors, and its stockholders, and the resultant need to fragment the entity and identify its relevant components in order to determine whose "rights" are to be vindicated. For example, the component to which corporate counsel owes loyalty has been the subject of voluminous literature. See G. HAZARD, ETHICS IN THE PRACTICE OF LAW $50-53$ (1978); Lorne, The Corporate and Securities Advisor, the Public Interest, and Professional Ethics, 76 MICH. L. REV. 425 (1978); Sonde, The Responsibility of Professionals under the Federal Securities Laws-Some Observations, 68 NW. U.L. REV. 1, 9 (1973); Taylor, The Role of Corporate Counsel, in CORPORATIONS AT THE CROSSROADS, GoverNANCE AND REFORM 217 (D. DeMott ed. 1980). A similar fracturing of the "entity" is required to address the problem of corporate "standing" to vindicate "its" constitutional rights as opposed to its members' rights. Cf. Note, Associational Standing and Due Process: The Need For an Adeguate Representation Scrutiny, 61 B.U.L. REV. 174 (1981) (danger of inadequate representation of members in suits by associations). On a more prosaic level, the difference between the entity and the stockholders bedevilled the courts in the Old Dominion cases. Compare Old Dominion Copper Mining \& Smelting Co. v. Lewisohn, 210 U.S. 206 (1907) with Old Dominion Copper Mining \& Smelting Co. v. Bigelow, 203 Mass. 159, 89 N.E. 193 (1909), af'd, 225 U.S. 111 (1912). 
The Court's suggestion in Bellotti that the absence of a provision permitting unanimous stockholder approval to authorize the speech was a fatal defect in the challenged statute is not unrelated to the received learning on corporate waste-that unanimous stockholder approval can cure waste. Presumably, a state statute forbidding all wasteful corporate behavior, including but not limited to the expenditures made in Bellotti, would survive constitutional challenge if stockholder approval, even unanimous approval, could avoid its prohibition. ${ }^{64}$ The state's power to define the terms on which parties enter into corporate arrangements surely includes the power to prescribe when, and how much, stockholder approval is required in order to validate those corporate expenditures that the parties originally agreed would otherwise be wasteful. The First Amendment should not inhibit the non-discriminatory exercise of that state power merely because the concededly wasteful behavior thus made curable takes the form, inter alia, of communication. ${ }^{65}$ Focusing, however, on a more particularized problem-one addressed only to wasteful speech-raises a different question.

\section{B. Prohibitions on Only Wasteful Corporate Speech}

To move from a law that interdicts all indisputably wasteful expenditures of corporate funds to a statute that strikes only at indisputably wasteful expenditures for speech raises the question whether such communication is "protected speech." Should the singling-out of wasteful noncommercial speech, in contrast to other wasteful behavior by an errant agent, trigger First Amendment restraints? A state could reasonably conclude that management's waste of corporate assets by such speech is harder to detect or to police than other forms of waste, that expenditures

64. Justice Powell concedes that stockholders "generally have access to the judicial remedy of a derivative suit to challenge corporate disbursements [including expenditures for 'debate on public issues'] alleged to have been made for improper corporate purposes or merely to further the personal interests of management." 435 U.S. at 794-95. Yet the Court also states that legislative prohibition of such waste, sanctioned by criminal penalties, infringes the First Amendment. Id. at 785-86. Possibly the Court's reifying the corporation and reading the statute to preclude the utterance of the corporate message by anyone (even with unanimous stockholder approval) if the reified corporation was thus forbidden from speaking caused the apparently contradictory statements. See note 109 infra. But to recognize that the human beings who constitute the corporation can be consulted and can speak collectively apart from the corporation precludes the conclusion that if it is forbidden from speaking, they are also so forbidden.

65. Justice Powell's suggestion, however, that Justice White's dissent is in error because it implies that "corporate activities [public service ads for charitable causes] that are widely viewed as educational and socially constructive could be prohibited," 435 U.S. at 782 n.18, strikes a bizarre note. Certainly nothing in the Constitution prevents a state from forbidding a corporation to make charitable contributions, that is, conditioning all sales of stock on a promise not to spend any funds for charity having nothing to do with the corporate business. If the state does so, it is difficult to see why the prohibition may not extend to expenditure of funds for ads praising the charity or urging contributions to it. 
for such speech are more likely than other forms of expenditures to serve only managerial interests (rather than mistaken estimates of collective interests), and that such expenditures are less likely to produce returns to the misappropriator that would enable the stockholders to recover from him. The state might, therefore, seek to deter wasteful speech by a more severe sanction than that applied to other forms of waste. ${ }^{66}$ Singling out such impropriety for special treatment would be constitutional if, as this reasoning suggests, the state has a "rational basis" for the special treatment, and if, in addition, the proscription need not be tested by First Amendment standards of substance or procedure.

A persuasive case can be made that the proscription need not be so tested. But even if it must be so tested, there is good reason to believe it would meet such a test. If the speech is concededly wasteful, the reasons for using First Amendment standards to measure the constitutionality of restrictions on speech do not apply. The restrictions are directed not at the communicating function of speech-its particular content, subject matter, or the receipt of its message by others-but at the creation of waste, which happens to take the form of spending funds to communicate something that is beyond the limited concerns of the corporate venture and in violation of the agreement of the corporate venturers. The communication is not restricted in order to frustrate the sending of any message by the president with his own funds or to prevent the receipt of a message by others. It is restricted because the act of utterance is, by definition, an expropriation of the collective assets of all the owners. It is an expropriation regardless of whether the words are gibberish or a coherent message. The considerations that invoke the protection of the First Amendment should no more inhibit the state from so defining expropriation, or from requiring unanimous stockholder consent for such diversions of assets, than they limit the state's power to prohibit communications that constitute fraud or to prohibit the use of particular language in income tax returns, in applications for licenses to erect nuclear reactors, or in contracts that violate the antitrust laws. ${ }^{67}$ Indeed, the First Amendment can hardly be more rele-

66. For example, the state might set a criminal penalty when other forms of waste are subject only to civil liability or injunction.

67. See Farber, Commercial Speech and First Amendment Theory, 74 NW. U.L. REV. 372 (1979); cf. Giboney v. Empire Storage Co., 336 U.S. 490 (1949) (union members enjoined from picketing ice distributor's business where purpose was to discourage sale of ice to nonunion retailers, and actions constituted an unlawful restraint of trade). It does not alter this conclusion that when the antitrust laws have been invoked against trade associations or groups seeking political action or judicial or administrative decision their scope has been determined in light of First Amendment considerations which are invokable by the individual violators of the antitrust laws. See UMW v. Pennington, 381 U.S. 657, 669-70 (1965); Eastern R.R. President's Conf. v. Noerr Motor Freight, Inc., 365 U.S. 127, 137-40 (1961). But cf. Otter Tail Power Co. v. United States, 410 U.S. 366, 379-80 (1973) (litigation brought to maintain monopolistic position may not be constitutionally protected); California Motor Transp. Co. v. Trucking Unlimited, 404 U.S. 508, 513-15 (1972) (First Amendment right to 
vant in the case of corporate waste, in which the communicative impact of the message is quite immaterial, than it is in the latter cases, in which the message conveyed is an integral part of the prohibited behavior.

To be sure, there is room to argue under the equal protection clause whether the state can prohibit wasteful speech but not other forms of waste, such as investment in a forbidden business, or whether it can prohibit some modes of expropriation that depend upon speech, such as fraud, by different criteria and sanctions than it uses to prohibit other modes of expropriation, like embezzlement or robbery. But those arguments turn on whether the government's choice has a rational basis. They do not become disputes under the First Amendment merely because the utterance of words is involved, whether the communication constitutes fraud or waste.

That conclusion may not follow quite so inexorably from the premise of "waste" if a prohibition is addressed only to particular kinds of wasteful speech, and not to all kinds. For example, a law might prohibit ads for products having no conceivable relation to the company without forbidding similarly irrelevant political speech, or, as in Bellotti, might prohibit some wasteful political speech but not all wasteful speech. Since the communication is by definition "waste," and therefore not protected speech, it may plausibly be argued that the taut First Amendment criteria of overinclusiveness and underinclusiveness must yield to the "rational basis" test under the equal protection clause. ${ }^{68}$ On the other hand, when the stricture seems to be aimed at only a very narrow kind of political speech, and only on a particular topic, a court may reasonably suspect that the concern of the legislature is not "waste" but silencing the expression of particular views. Such pinpointing may be sufficient to invoke the First Amendment as the appropriate test of the propriety of the legislation. But a different question is presented if the state seeks to interdict all wasteful political speech made by "the" corporation without stockholder consent.

When all wasteful political or noncommercial speech is forbidden, the scope of the statute fits the scope of the problem. It protects the rights of the stockholder against a particular form of "waste" that is singled out not

petition does not necessarily immunize initiation of agency and judicial proceedings from antitrust laws).

68. In contrast, the Court in Bellotti invoked First Amendment criteria to test the validity of the Massachusetts statute, and required that the statute further a compelling state interest, be narrowly drawn to infringe only that speech necessary to achieve the compelling state interest, and be drawn broadly enough to reach all similar behavior. 435 U.S. at 786-95. To say that the legislation was overinclusive in precluding corporate speech even with unanimous stockholder consent, and underinclusive in that it did not reach aggregations of capital other than corporations, raises conventional "equal protection" questions. But the Court reviewed these issues with the kind of critical judicial scrutiny that is traditionally reserved to measure unequal deprivations of First Amendment rights. See Karst, supra note 55. 
for its communicative capacity, but because it is more difficult to detect than other forms of waste, more likely to be used to implement management's personal views, and less likely to create assets that stockholders can recover from errant management. The scope of the special treatment of such wasteful speech is thus no narrower and no broader than the evils the government seeks, and is entitled, to prevent. Such a law does not, therefore, raise a serious question whether its target is the communication of ideas to other persons, or even the content of particular speech; thus, the legislature is entitled to the presumption that its goal is the regulation of a form of waste and not the suppression of messages.

If the First Amendment should require more exacting judicial scrutiny of such legislation, because the legislation specifically regulates communication, albeit waste, the legislation can survive that scrutiny. ${ }^{69}$ But that inquiry implicates a broader question-and a more significant justification for the restriction. ${ }^{70}$

\section{Intra Vires Speech: The Requirement of Stockholder Consent}

At the outset it is worth emphasizing that, notwithstanding the variations permitted in corporate charters, the state normally determines the process by which individual investors in the corporation may reach corporate decisions. For example, if an enterprise is incorporated to engage only in the shoe business, the state can, and does, prescribe the terms on which the participants may later agree to enable the firm to engage in an additional business, such as food processing, or to eliminate a part of the shoe business, such as synthetic products or men's shoes. To that end, the state may restrain, or permit the parties to restrain, management or each other from using collective assets to communicate with stockholders concerning

69. The legislation would certainly satisfy the criteria of United States v. O'Brien, 391 U.S. 367 (1968), and, if viewed as implementing the investors' contract, could also plausibly meet the more demanding requirements that may be invoked when only speech is singled out for special restriction. See note 68 supra.

70. The relationship of the stricture to the First Amendment would be closer if there were reason to believe, in any particular instance, that the particular speech singled out for special restraint is not waste. Possibly the Court believed that the speech the Massachusetts statute prohibited was "protected speech" because it was not "waste" under corporate law, 435 U.S. at 784, and therefore should be treated as "protected" because management could make such speech without violating the contract of the participants. The Court did not dispute the finding of both the Massachusetts legislature and the Massachusetts Supreme Judicial Court that the referendum in question did not materially affect the corporation's business. First Nat'l Bank v. Attorney Gen., 371 Mass. 773, 785, 359 N.E.2d 1261, 1270 (1977), rev'd sub nom. First Nat'l Bank v. Bellotti, 435 U.S. 765 (1978). Possibly, the Court believed that expenditure on a political question "other than one materially affecting any of the property, business or assets of the corporation" covers more than merely "ultra vires" or "waste"; on that premise the Court may have concluded that the state cannot by statute declare action to be "waste" or ultra vires if the Court thinks it is not. Alternatively, the Court may have believed that the statute did not make the particular expenditures equivalent to waste, and thus did not subject management to liability to stockholders. 
changes in the charter arrangements. The First Amendment has little, if any, effect on the state's authority to regulate such internal communications, whether they are made by management to stockholders or among stockholders, so long as the communications address only the implementation or alteration of those internal arrangements. ${ }^{71}$ It is only when corporate communications, even if made internally, as by management to stockholders, are addressed to a broader subject matter than the implementation or alteration of the parties' contractual arrangements that the First Amendment may become relevant. As we have seen, if that speech is concededly beyond any power the participants have given the enterprise to exercise, the state may prohibit it without offending the First Amendment. Why should First Amendment considerations intrude when the state seeks to restrict the internal decisionmaking process with respect to speech that is within the power of the organization to make?

There is little reason for First Amendment criteria to test many forms of government regulation that apply in a non-discriminatory manner to all corporations, including those engaged in the business of communicating. ${ }^{72}$

71. Few ripples from the First Amendment affect state or federal law restraints on the use of communications among stockholders to effect such legally permissible alterations in the enterprise. The states have traditionally regulated-without reference to the First Amendment-stockholder access to the means of communicating with other stockholders about corporate affairs. See State ex rel. Pillsbury v. Honeywell, Inc., 291 Minn. 322, 191 N.W.2d 406 (1971). Similarly, for almost half a century the federal government has-without any significant reference to the First Amendment-regulated management's and stockholders' use of the proxy system to communicate with other stockholders concerning corporate affairs. See SEC v. May, 134 F. Supp. 247 (S.D.N.Y. 1955), aff'd, 229 F.2d 123 (2d Cir. 1956); 17 C.F.R. $\$ \S 240.14 a-8$, -9 (1980) (Rules 14a-8 and 14a-9, pursuant to Securities Exchange Act of 1934, imposing restrictions on stockholder proposals and general restraints of proxy rules). See also Brown v. Chicago, R.I. \& Pac. R.R., 328 F.2d 122 (7th Cir. 1964); Union Pac. R.R. v. Chicago \& N.W. Ry., 226 F. Supp. 400 (N.D. Ill. 1964); W. CARY \& M. EISENBERG, CORPORATIONS 288-89 (5th ed. 1980); Note, supra note 11, at 841-49.

To be sure, the Supreme Court has warned, in the labor union context, that under the First Amendment "the gravest doubt" would arise from a prohibition against "publication, by corporations and unions in the regular course of conducting their affairs, of periodicals advising their members, stockholders or customers of danger or advantage to their interests from the adoption of measures, or the election to office of men espousing such measures . . .." United States v. CIO, 335 U.S. 106, 121 (1948); cf. United States v. UAW, 352 U.S. 567, 593 (1957) (Douglas, J., dissenting) (union's right to express views on political election essential to self-government). Possibly, therefore, speech by management to stockholders on matters that intersect both the mechanics of internal decisionmaking or corporate business operations generally and public issues may stand on a different footing than does the normal grist for the proxy mill, although the point appears never to have been seriously raised in that context.

But this warning must be qualified on two grounds. The need to use the group's funds to communicate with members of the enterprise about government action or public views that threaten its operations or prosperity need not invoke First Amendment considerations for corporations even if it may do so for unions. See notes 89 \& 206 infra. In any event, a line of later decisions, beginning with Railway Employees Dep't v. Hanson, 351 U.S. 225 (1956), see note 86 infra, teaches that exhortation of investors, members, or other participants in a group enterprise to take political action to preserve the enterprise or its prosperity may be entitled to the protection of the First Amendment, but that such protection does not require or even-permit the government to compel investors or members to fund such exhortation.

72. Sec, e.g., Oklahoma Press Publishing Co. v. Walling, 327 U.S. 186, 192-94 (1946) (applica- 
But there may be good reason to invoke First Amendment standards to test a generally applicable regulation that allocates internal corporate decisionmaking among stockholders when applied to a communications business. ${ }^{73}$ It does not follow, however, that government should be equally inhibited if the regulation governs only corporations not engaged in the business of communicating. The First Amendment should not present an insurmountable obstacle to such a regulation, whether it is (1) applied equally to all activities, including the communication activities, of such corporations, or (2) addressed only to political communications made by such enterprises.

\section{A. Stockholder Consent Requirements that Do Not Single Out Corpo- rate Speech}

Let us assume an enterprise not engaged in the communications business, such as a cigarette manufacturer, and deal with a state's effort to give its stockholders a larger voice over some business matters-sales to minors, for example-than over others. Further assume that the state requires management to obtain unanimous stockholder approval for any contract for the sale of cigarettes that fails to prohibit resale to minors. Assume that the state also requires similar stockholder approval for all advertising campaigns intended or likely to induce purchases by minors, but does not require such stockholder approval for any action, including advertising, that is not likely to affect minors. Should the First Amendment test the propriety of such regulation?

Since communication is not singled out for special treatment-both sales and advertising are subject to the same requirement-it is hard to see why such state-imposed restraints should not be free of the inhibitions of the First Amendment. We are told that "[c]ommercial expression not only serves the economic interest of the speaker, but also' assists consumers and furthers the societal interest in the fullest possible dissemination of information." ${ }^{\prime 74}$ If we focus, for the moment, solely on the consumer's interest in the utterance, and assume that we are dealing only with the communication of an offer to sell that has no further implications by way of

tion of Fair Labor Standards Act to newspapers does not violate First Amendment); Associated Press v. NLRB, 301 U.S. 103, 130-33 (1937) (application of National Labor Relations Act to press does not abridge freedom of speech or press).

73. If the regulated organization is specifically created to engage in the business of communicating, e.g., Grosjean v. American Press Co., 297 U.S. 233 (1936), or is otherwise created for activities which entail its members' First Amendment rights, e.g., Murdock v. Pennsylvania, 319 U.S. 105 (1943), the First Amendment restricts the government's power to single out such an organization for special disadvantage, or to impair its ability to perform its normal communicating functions. See note 89 infra.

74. Central Hudson Gas \& Elec. Corp. v. Public Serv. Comm'n, 447 U.S. 557, 561-62 (1980). 
conditioning taste, urging political action, or otherwise, the communication is no more than a part of the effort to engage in the effectively forbidden transaction. ${ }^{75}$ If thus viewed as only making an offer, the communication is either fraudulent, because it cannot be lawfully consummated, or an inducement to join in the forbidden behavior, which no more raises a problem under the First Amendment than does solicitation by a prostitute, whether made face-to-face or in public print. ${ }^{76}$ If the thrust of the statute is to forbid the sale of the commodity, the First Amendment does not protect the seller's ability to offer it or the consumer's entitlement to learn about it by ads or other forms of communication, except to the extent that such communications serve some function beyond informing the consumer's choice of goods or services.

Viewing the problem from the perspective of the corporate seller does not suggest a different conclusion. If the state entitles individual stockholders to a voice in deciding which commodities the corporation may sell, nothing in the First Amendment should qualify state power to give stockholders an equivalent voice in all aspects of the manufacture or sale of those commodities, including their advertisement. Thus, for the state to limit the discretion of the participants in a business venture to allocate decisionmaking power should not raise a question under the First Amendment, unless corporate speech is singled out for special treatment. To that question we now turn.

\section{B. Stockholder Consent Requirements that Single Out Corporate Politi- cal Speech}

We can best illustrate that question by eliminating from the example the requirement of stockholder approval of both sales and ads, and substituting instead a statutory prohibition against sales of cigarettes to minors and a statutory requirement of stockholder approval before any corporate assets are used to oppose any legislation, including the prohibition on cigarette sales to minors. Corporate ads urging repeal of the legislation would then squarely present the problem of corporate "political" speech.

As we have seen, even if the corporation itself is treated as a separate, impenetrable persona having a right to be free from government restriction on its speech, some rationale is necessary in order to invoke the First

75. A communication that does more than merely offer to sell requires further analysis. See pp. 281-86 infra.

76. See Pittsburgh Press Co. v. Pittsburgh Comm'n on Human Relations, 413 U.S. 376, 388 (1973). See also Central Hudson Gas \& Elec. Corp. v. Public Serv. Comm'n, 447 U.S. 557, 564 n.6 (1980). The considerations that protect advocacy of illegal behavior as a necessary component of freedom of speech, see Brandenburg v. Ohio, 395 U.S. 444 (1969); G. GUNTHER, CASES AND MATERIALS ON CONSTITUTIONAL LAW 1118-94 (10th ed. 1980), do not apply equally in the context of seeking to induce commercial transactions. See note 182 infra. 
Amendment to inhibit state efforts to prescribe a method of decisionmaking by the individual participants in the corporate venture on matters of interest to them when political speech is involved. The First Amendment does not prohibit, or indeed affect, state statutory or common law authorizing a contractual arrangement by the participants, voluntarily made part of the corporate charter, that provides for their special consent for political speech by the corporation. ${ }^{77}$ If instead the state conditions the banding together of the investors in a corporate venture on adoption of a special consensual procedure for expenditures of corporate funds on such speech, is there any better case for invoking the First Amendment to test the propriety of the condition?

\section{The Legitimacy of the Government's Interests}

If the state precludes private parties from contracting to delegate control over political speech to management or to a mere majority of stockholders, it undoubtedly restricts the freedom of speech of some stockholders, but expands the freedom of speech of others. ${ }^{78}$ More particularly, if the state precludes such arrangements, it offers greater freedom to the transient members of the minority at the expense of the transient members of the majority; to permit stockholders so to contract is to reverse that offer. In either case, since the state itself is, and historically always has been, the sole source of authority for such collective arrangements, the state is "acting." Accordingly, any enforcement the state offers to, or restrictions it places on, shareholders' contractual arrangements for collective political speech by a business corporation denies to some individuals unrestricted

77. The state apparently may permit a private group to condition an individual's opportunity to invest in the group's commercial venture on his advance consent to let management or even a majority of the participants spend the venture's funds on political speech they believe to be in the firm's interests. Any such arrangement proposes a relinquishment of the individual participant's control over the use of his funds for political expression. But the rules are not entirely clear. There is little doubt that for the state to compel such relinquishment would violate the First Amendment. See Wooley v. Maynard, 430 U.S. 705 (1977) (state may not require individuals to disseminate ideological message displayed on automobile license plates); West Virginia State Bd. of Educ. v. Barnette, 319 U.S. 624 (1943); note 54 supra. Moreover, the union shop cases suggest that for the government to authorize private imposition of such conditions for investment in commercial enterprise would, at least in those circumstances, violate the First Amendment. See Abood v. Detroit Bd. of Educ., 431 U.S. 209 (1977); Pipefitters Local 562 v. United States, 407 U.S. 385 (1972); Brotherhood of Ry. \& S.S. Clerks v. Allen, 373 U.S. 113 (1963); International Ass'n of Machinists v. Street, 367 U.S. 740 (1961); pp. 268-69 infra. Whether or not the decisions imply a constitutional prohibition against corporate officers' use of the corporation's funds for political purposes, the activities of private parties that the state permits are not without their restrictive effect on individual investors' exercise of rights of speech.

78. A refusal to permit appropriation of contributed resources is a rational response to a difficult allocation problem, similar to a government mandate designed to regulate the sharing of presumably scarce resources for purveying information and to avoid conflict from uncontrolled access to such resources. See Red Lion Broadcasting Co. v. FCC, 395 U.S. 367 (1969); Associated Press v. United States, 326 U.S. 1 (1945). 
choice in the use of their invested funds for political speech. Thus, the question whether the First Amendment prohibits the state from requiring unanimous stockholder approval before corporate funds are used to oppose legislation must be answered in light of the inevitability of some stateimposed burdens on the freedom of speech of some investors.

Legitimate government interest in such a requirement is suggested by the teaching of both (a) political science-a concern with the freedom of speech and political voice of individual investors-and (b) economic theory-a concern with the formation of capital.

\section{(a)}

A state could rationally conclude that freedom of speech is better preserved for individual investors if they are not obliged to give up some of that freedom to management or to a majority of their fellow investors as a condition of making an investment in a commercial enterprise that is not engaged in the business of communicating. A state could also rationally conclude that management is not entitled to use any discretion in such matters. ${ }^{79}$ Finally, it could reason that a requirement of unanimous consent does not improperly restrict either those investors who favor particular expression or society's interest in the dissemination of such speech, so long as those majority stockholders whose views management might have faithfully reflected are free to band together, in a structure parallel to the business venture, to express themselves on the same subject and in the same way as the "entity" might have done.

State efforts to safeguard the First Amendment interests of shareholders, both majority and minority, may appropriately rest on the need to limit management's power to use corporate funds for noncommercial speech. Management's use of corporate assets to express its political preferences, social views, or opinions need bear little correlation with the political or social views of stockholders. Both in theory ${ }^{80}$ and in practice, ${ }^{81}$

79. Whether or not most managements support the same government activities or have the same views on social matters, see note 12 supra, it is not unreasonable for government to conclude that management should not have access to stockholders' assets to urge its views on society, no matter how plausibly essential management thinks those views are to corporate prosperity. To be sure, in an age of the welfare state and extensive government regulation of business, the entitlement of the collectivity to resist the regulation of its business operations may raise equal protection or due process questions. See generally C. LINDBLOM, supra note 12, at 170-200; note 96 infra.

80. The typical state corporation statute provides (and possibly requires) that stockholders delegate to management decisionmaking power over expenditure of funds to advance or protect corporate operations. See MODEL BUS. CORP. ACT ANN. \& 35 (Supp. 1977).

81. The possibility of displacement by stockholders is hardly likely to be a constraint on management's expenditures for speech on political matters or other matters of opinion, especially in light of management's control of the proxy system. Nor is disagreement over the spending of corporate funds on political or social speech apt to produce displacement by take-over. See Note, supra note 11, at 849. It is understandable when corporate counsel urges the notion that the internal processes of corporate democracy or the availability of derivative suits under present law is adequate to permit stock- 
management is substantially free to use corporate assets to urge any political or social views it sees fit, so long as it can establish a plausible connection between those expenditures and a long term commercial benefit to the corporation. Given the looseness that is sufficient to establish the necessary connection, ${ }^{82}$ few managements are likely to fail to make it.

Even if the realities of corporate suffrage and control are ignored, and it is assumed that the problem is protecting the rights of majorities within the corporation to speak politically through responsive management, this problem is more acute for investors in large publicly held business corporations than for participants in most other kinds of group activities. The process of funneling individual stockholders' political or social opinions through the business corporation distorts the representation of their views in a manner at odds with the premises of the political system. Voting in large publicly held corporations is by the share, not by the person; hence, the political power of individuals with large blocks of stock is magnified to the extent that they can control, for political purposes, the use of the assets of minority stockholders that are held in corporate solution..$^{83}$ Although the First Amendment may not require government to preclude the distorting effect of management or majority use of corporate assets for political purposes, it is difficult to find in it anything that precludes a state from attempting to prevent such distortion.

To acknowledge that requiring consent from more than a majority of the stockholders impedes "the corporation's" speech and the public's opportunity to hear it does not alter this conclusion. Any arrangement requiring prior consultation with stockholders before corporate exercise of

holder voices to dictate or alter, or even to affect, management's political spending of corporate funds, see Schaefer, The First Amendment, Media Conglomerates and "Business" Corporations: Can Corporations Safely Involve Themselves in the Political Process? 55 ST. JOHNS L. REV. 1, 8 n.37 (1980), but it comes as something of a surprise when a Supreme Court Justice judicially notices it, sce First Nat'l Bank v. Bellotti, 435 U.S. 765, 794-95 (1978) (Powell, J.), especially one whose professional life embraced service of corporate clients. Cf. Powell Memorandum, supra note 35 (memorandum to U.S. Chamber of Commerce).

82. The so-called business judgment rule is a virtual immunizer of such managerial judgments. See Brudney, supra note 6, at 614-15. Ironically, the movement for corporate social responsibility has considerably broadened the scope of acceptable managerial discretion.

83. That point is particularly relevant in determining the appropriate mode of generating a pool of funds for use in political matters. In the political process, individuals' political preferences are normally given equal weight; votes are not measured by wealth per person. Thus, a system of majority rule by vote of shares is somewhat incongruous as a basis for allocating collective funds in political matters. The institutional ownership of stock further complicates the issue; so does the resulting question of the proper relationship to the political process of the holders of institutions' stock (mutual funds) or of the institutions' beneficiaries or trustees in the case of, for example, ownership by churches, universities, or pension funds. See SEC REPORT, supra note 21, at 379-421. The possibility that voting power tied to share ownership might cause an undue concentration of political power was an early source of concern in several states. See Ratner, The Government of Business Corporations: Critical Reflections on the Rule of "One Share, One Vote", 56 CORNELL L. REV. 1, 6-8 (1970) (early legislation in some states provided for voting by shareholders rather than by shares). 
the power to speak, such as prohibiting delegation to agents, also impedes "the corporation" from speaking. Yet it does not follow that the First Amendment requires the state to permit owners to delegate such powers to managers who have no obligation even to consult stockholders. ${ }^{84}$ Nor does the possibility that the requirement to consult stockholders impedes the corporation's speech to a degree that would be constitutionally intolerable if imposed on individual speech make the impediment offensive to the First Amendment. Group action-whether in the form of speech or otherwise-is legitimately and traditionally subject to greater regulation by government than is individual action. It is the impact of government regulation on the ability of the individual members of the group to act collectively in order to implement or protect their individual First Amendment interests that should determine the validity of such laws.

It has been suggested that because individuals' rights of expression entitle them to amplify their views by collective expression, a requirement of unanimous consent would run afoul of the First Amendment. The notion appears to be that the First Amendment requires government to permit simple "majority rule" within a group when the group's funds are used for political speech. ${ }^{85}$ There is little basis in $\operatorname{law}^{86}$ or logic for that notion,

84. But $c f$. Bolton, supra note 3, at 413 (suggesting need to delegate making of political judgments within corporation).

85. See United States v. UAW, 352 U.S. 567, $596-97$ (1957) (Douglas, J., dissenting); United States v. CIO, 335 U.S. 106, 143-49 (1948) (Rutledge, J., concurring). See also First Nat'l Bank v. Bellotti, 435 U.S. 765, 794 n.34 (1978); International Ass'n of Machinists v. Street, 367 U.S. 740, $772-73$ (1961). But see Bolton, supra note 3, at 400 (noting apparent contradiction between this view and rationale of Street and Hanson).

One theory is that a rule that allows a majority to use only its own funds and relieves the minority of the obligation to contribute to effectuation of the group's collective bargaining purposes creates a free rider problem that disadvantages the majority. See M. OLSON, THE LOGIC OF COLLECTIVE AC. TION 66-97 (1971); Comment, The Constitutionality of the Federal Ban on Corporate and Union Campaign Contributions and Expenditures, 42 U. CHI. L. REV. 148, 155 (1974). But the theory of the First Amendment right of association does not preclude such a disadvantage. Indeed, that disadvantage inheres in democratic voting systems. In theory, the free rider cost to the majority is trivial compared to the cost of forcing the minority to speak against its will. On a practical level, pressures of group membership may dilute free rider costs. Not only is there peer pressure, and in the case of unions possibly covert coercion, but the members of the union may not view the enterprise solely in economic terms. Union members may reap the same kind of altruistic returns general contributors receive from donations to political campaigns.

86. The Railway Labor $\Lambda c t$ and perhaps also the Taft-Hartley $\Lambda \mathrm{ct}$ authorize exclusive bargaining-union shop arrangements. See Comment, The Regulation of Union Political Activity: Majority and Minority Rights and Remedies, 126 U. PA. L. REV. 386, 416-20 (1977). These Acts were once thought to permit the union leadership to use union funds for political activities in the interest of the membership. Indeet, such use was thought to be a constitutional entitlement derived from the notion of majority rule within the union. See United States v. UAW, 352 U.S. 567, 596-97 (1957) (Douglas, J., dissenting); United States v. CIO, 335 U.S. 106, 143-49 (1948) (Rutledge, J., concurring); cf. DeMille v. American Fed'n of Radio Artists, 31 Cal. 2d 139, 187 P.2d 769 (1947), cert. denied, 333 U.S. 876 (1948) (union may use dues to oppose legislation if union constitution states that such action is one purpose of union). But the Court has more recently opined, although it has not squarely held, that the nexus between the union arrangements that the Railway Labor $\Lambda$ ct and some state statutes permit and government "action" is apparently close enough to subject union leaders acting under those arrangements to the restrictions of the First Amendment. Thus, the First Amendment rights of 
except when a simple majoritarian rule is necessary for the functioning of a group formed for the purpose of engaging in speech or vindicating other rights the First Amendment protects. ${ }^{87}$ Perhaps all groups would be entitled to such "majority rule" if associative rights derived only from the First Amendment. ${ }^{88}$ But more plausibly, as the Court has suggested, it is only those associative rights that are exercised to implement or amplify other First Amendment rights, such as freedom of speech and of the press, that the First Amendment should protect against government regulation of the association's external behavior or internal decisionmaking. ${ }^{89}$

individual union members are violated when union leaders spend union funds to espouse political views that some members oppose, even though the espousal is on behalf of the members' collective interest. See Abood v. Detroit Bd. of Educ., 431 U.S. 209 (1977); Brotherhood of Ry. \& S.S. Clerks v. Allen, 373 U.S. 113 (1963); International Ass'n of Machinists v. Street, 367 U.S. 740 (1961); Railway Employees Dep't v. Hanson, 351 U.S. 225 (1956). See also Beck v. CWA, 468 F. Supp. 93 (D. Md. 1979).

87. At common law, majority rule became an assumed feature of the contract among members of a corporation. R. STEVENS, supra note 40 , at 565 n.1. Deviation from such a rule was contemplated, however. States, by legislation, could alter that rule, and stockholders were permitted to contract for a unanimity requirement. In fact, for matters not functionally related to day-to-day decisonmaking, a rule of unanimity was operationally tolerable, and actually prevailed. See note 40 supra.

A group formed for the purpose of engaging in speech presumably will engage in speech frequently, if not daily. To require even simple majority, let alone supermajority, consent before each such utterance would virtually preclude the group from fulfilling its purpose. Thus, regulating the internal decisionmaking of such groups to require frequent consultation with membership poses a substantial First Amendment problem. See L. TRIBE, supra note 54, at 704; cf. Democratic Party v. LaFollette, 101 S. Ct. 1010, 1018-20 (1981) (government interference with seating of delegates to national party convention violates First Amendment rights of party members); Cousins v. Wigoda, 419 U.S. 477 , 489-91 (1975) (state regulation of national party delegate selection unconstitutionally impairs nomination process); Kusper v. Pontikes, 414 U.S. 51 (1973) (statute prohibiting voters from voting in a party's political primary if they have voted in a different party's primary within 23 months violates voters' rights of free political association); Healy v. James, 408 U.S. 169 (1972) (state university's refusal to grant student political group privileges afforded other student organizations violates students' free speech and associational rights).

88. See Baker, Scope of the First Amendment Freedom of Speech, 25 U.C.L.A. L. REV. 964, 1029-31 (1978).

89. The First Amendment's prohibition against laws abridging the "right of the people peaceably to assemble" is offered in the context of protecting freedom of speech, freedom of the press, and access to government. See Citizens Against Rent Control/Coalition for Fair Housing v. City of Berkeley, 102 S. Ct. 434, 437-39 (1981). That provision offers protection to the activities of associations, like the NAACP, that are formed and function primarily to vindicate members' First Amendment rights. Indeed, it may be that purpose of such organizations that underpins First Amendment protection for their associational activities. See, e.g., NAACP v. Button, 371 U.S. 415, 430-31 (1963); Shelton v. Tucker, 364 U.S. 479, 485-86 (1960); NAACP v. Alabama, 357 U.S. 449, 459-60 (1958), L. TRIBE, supra note 54 , at $700-08$.

If, in an enterprise formed primarily to implement members' First Amendment rights, the government is permitted to hamper the majority's effectiveness by a requirement of unanimous consent designed to protect the minority, then the government can effectively cripple all efforts at amplification of individuals' First Amendment rights of expression by collective action. Not only may government thus effectively silence the first association, but it could prevent the majority of that group from forming another such enterprise for the purpose of collectively engaging in speech, since the new enterprise would be exposed to the same peril. But no such silencing effect occurs if the government's power to protect the minority by a requirement of unanimous consent is confined to enterprises not formed for the purpose of implementing their members' First Amendment freedoms. In such a case, the ability to form another association for the purpose of amplifying members' First Amendment rights is available as a safety valve. 
The considerations supporting First Amendment protection for the internal decisionmaking of such associations do not apply equally to a publicly held noncommunications business venture ${ }^{90}$ when it seeks to make political utterances. ${ }^{11}$ Such an enterprise is not formed to amplify its investors' First Amendment rights. Nor does it have the personal autonomy that enables individuals to exercise noneconomic preferences, ${ }^{92}$ and for which the First Amendment seeks to assure fulfillment in self-expression. On the contrary, it is the corporation's stockholders whose right to speak and refrain from speaking is at issue. Nothing in the First Amendment compels the state, in order to give the most appropriate protection to the individual's freedom of expression, to choose between permitting shareholders in such a venture to delegate to a majority or to management the authority to use collective funds for political speech or requiring unani-

90. The argument for simple majority rule presumably rests on the assumptions that majority coalitions of autonomous individuals are easily formed in a free society, that majority coalitions are not permanent but are pliable, and that such coalitions are able to form and reform in order to replace leadership that fails to implement the majority's aspirations. Whether or not that model correctly reflects majority rule in trade unions or other groups that conform to the principle of "one man, one vote," it bears little resemblance to publicly held corporations, where voting is by shares. See Manne, Some Theoretical Aspects of Share Voting, 64 CoLUM. L. REV. 1427 (1964). Management's control of the proxy system further discourages use of the model of majority rule to describe those corporate decisions on which stockholders are consulted. In addition, the percentage of the voting constituency that participates in the voting is apt to be smaller in public corporations than in other groups like unions or trade associations from which exit is more costly, and in which collective decisions tend to have greater immediate impact on individual members.

91. In the case of a corporation not engaged in the business of communicating, a government requirement of supermajority consent for political speech would not interfere with the corporation's daily operations. Nor would it unduly restrict individuals' right to speak, since that right is collateral to the purpose of the corporation, compare Ohralik v. Ohio State Bar Ass'n, 436 U.S. 447 (1978) (state bar disciplinary action against attorney for soliciting business held constitutional) with In re Primus, 436 U.S. 412 (1978) (state bar disciplinary action against ACLU lawyer for soliciting business violates First Amendment), and may be exercised collectively by forming a new association for that purpose.

92. The range of preferences open to business corporations as economic instruments is much narrower than that open to individuals. The latter plainly may prefer noneconomic goals over economic objectives, but the former are presumably confined to maximizing investor wealth. Business corporations have no legitimate role in vindicating-or intruding into-the noneconomic interests of their individual investors by political action. See First Nat'l Bank v. Bellotti, 435 U.S. 765, 805-06 (1978) (White, J., dissenting); FEC v. Weinsten, 462 F. Supp. 243, 249 (S.D.N.Y. 1978); O'Kelley, supra note 30 , at 1349-51. The notions of pluralism and of the essential role groups play in a democratic polity, see D. TRUMAN, GOVERNMENTAL PROCESS (1971), even if they otherwise illuminate the scope of the First Amendment, see Wright, Politics and the Constitution: Is Money Speech? 85 YALE L.J. $1000,1013-17$ (1976), do not require homogenization of all groups, so that business corporations and the American Civil Liberties Union or Common Cause become equivalent "groups" through which participants exercise political rights and free speech. But cf. E. EPSTEIN, THE CORPORATION IN AMERICAN POLITICS 221-30 (1969) (corporations are merely one of several social interest groups that possess equivalent political assets); Bolton, supra note 3, at 414-16 ("irrational" to limit corporate political activity and not that of other interest groups.)

Unquestionably, it is difficult to delineate groups formed for the purpose, "primary" purpose, or central objective of amplifying individual members' First $\Lambda$ mendment interests, and to separate them from enterprises with substantial, if not quite central, interests in such purposes. But those difficulties are not serious obstacles to placing publicly held business corporations well on one side of the line-as long as the business corporation is not a hybrid. See pp. 290-91 infra. 
mous stockholder consent for such speech. ${ }^{93}$ But it does not self-evidently forbid the state from imposing a requirement that is designed to assure maximum individual choice in the matter, without precluding either collective action outside the corporate structure or individual contributions to enable the particular speech to be made. Indeed, since a state's failure to require stockholder consent will leave individuals subject to the condition that in order to make investments they must relinquish full control of their resources for making political speech, it is hard to see how the First Amendment (or its mode of testing the constitutionality of restrictions on speech) can answer the problem. Nonetheless, its message points to the permissibility of the state's choice to require stockholder consent. ${ }^{94}$

No less important may be the government's interest in expanding the political power of individuals and limiting that of business corporations by unbundling the latter's political activities from their economic function.95 The government may seek to limit business corporations' political activity in order to confine them to their economic roles. ${ }^{96}$ Whatever may be the "right" of a business corporation organized for profit-making purposes to

93. But cf. Abood v. Detroit Bd. of Educ., 431 U.S. 209, 234-35 (1977) (union political speech must be financed through voluntary employee contributions); Brotherhod of Ry. \& S.S. Clerks v. Allen, 373 U.S. 113, 118-19 (1963) (dues of union members who object to union political activity cannot be used for such activity); International Ass'n of Machinists v. Street, 367 U.S. 740 (1961) (same); pp. 268-69 infra (discussing union cases).

94. As the Court has pointed out:

Surely a command that the government itself shall not impede the free flow of ideas does not afford non-governmental combinations a refuge if they impose restraints upon that constitutionally guaranteed freedom. . . . Freedom to publish is guaranteed by the Constitution, but freedom to combine to keep others from publishing is not.

Associated Press v. United States, 326 U.S. 1, 20 (1945). See Lorain Journal v. United States, 342 U.S. 143 (1951); cf. Marsh v. Alabama, 326 U.S. 501 (1946) (company-owned town must allow freedom of speech). On that logic, nothing in the First Amendment should deny government the power to intervene to protect an individual stockholder from being forced to couple his investment with permission for managers to use corporate assets for political speech that he opposes. It cannot plausibly be argued that the First Amendment forbids one state from prohibiting what it forbids another state from permitting. See First Nat'l Bank v. Bellotti, 435 U.S. 765, 814-15 (1978) (White, J., dissenting). Compare Lloyd Corp. v. Tanner, 407 U.S. 551 (1972) (shopping center owner can deny free speech to persons seeking access to shopping center for that purpose) with Pruneyard Shopping Center v. Robins, 447 U.S. 74 (1980) (within constitutional power of state to require such access).

95. Cf. Cammarano v. United States, 358 U.S. 498, 512-13 (1959) (notion of "tax equilibrium" said to justify denial of tax deduction on ordinary and necessary business expenses for indirect political expenditures to eliminate political advantage for business not available to citizens concerned with political action unrelated to their business); Southwestern Elec. Power Co. v. United States, 312 F.2d 437, 448 (Ct. Cl. 1963) (Davis, J., dissenting) (deductibility of expenses related to appearance of company officers before congressional committees gives business unfair tax advantage); IRS Hearings, supra note 10, at 47-53, 182-83, 195-99 (non-enforcement of non-deductibilty of indirect political expenditures violates "tax equilibrium" concept); Lambert, supra note 2, at 1069 n.142 ("tax equilibrium" may require that both individual and corporate taxpayers be allowed to deduct their indirect political expenditures). But cf. Cooper, The Tax Treatment of Business Grassroots Lobbying: Defining and Attaining the Public Policy Objectives, 68 CoLUM. L. REV. 801, 810-16 (1968) (challenging notion of "tax equilibrium").

96. See note 92 supra. 
support political action to protect its "property," First Amendment considerations need not preclude government efforts to separate the corporation's power to affect political choices from its power to exercise economic preferences.7 In order to enhance individual investors' participation in such political choices, ${ }^{98}$ that effort can rationally take the form of requiring individual stockholder consent for such corporate action. To prohibit a systematic requirement that investors make joint choices in political and economic matters frees them to make separate personal choices in each, but does not preclude them from making collective decisions in either.

To be sure, the transient members of the "majority" are thereby denied the "full" political effectiveness that their speech might have if they or "their" management could use the corporate treasury to fund their utterances. But alternative modes of collectively funding political messages are available, although they impinge, in varying degrees, on the effectiveness of the use of the funds to further the majority's speech.9 Where, if anywhere, along the spectrum of possibilities for such collective speech without use of the minority's funds a constitutional line must be drawn, may be left for later analysis. It is sufficient for present purposes to note that in

97. If the large business corporation is viewed simply as a profit-maximizing enterprise in a free market economy, there is a puzzling circularity in empowering it to use political action to define the rules of "profit maximizing" and to determine its own claims on social resources-for example, who bears the costs of the externalities it creates-as against individual claimants on those resources. To be sure, permitting the firm to make political expenditures does not vest in it full power to make such determinations. But if solution of the circularity problem requires restrictions on such power, society could reasonably conclude that permitting firms to make political expenditures goes too far down the road to such power. If large corporate firms are recognized as long-term economic decisionmakers for the entire society, albeit subject to profit constraints, there is an equally difficult problem in legitimating their entitlement to the power to prevent the imposition of social constraints on their economic behavior. See Reich, supra note 12. Again, society could reasonably conclude that allowing authority in firms to make political expenditures travels too far down the road to such power.

That the First Amendment generally protects individuals' speech in business matters, but cf. Baker, Commercial Speech: A Problem in the Theory of Freedom, 62 Iown L. REV. 1 (1976) (First Amendment does not protect commercial speech because such speech fails to further speaker's liberty), does not mean that it similarly protects the speech of large publicly owned business corporations. The individual investors retain their individual entitlements under the First Amendment and may still organize to speak collectively on behalf of the same objectives, but in a vehicle other than the corporation.

98. See Patton \& Bartlett, Corporate "Persons" and Freedom of Speech: The Political Impact of Legal Mythology, 1981 WIS. L. REV. 494.

99. If unanimous consent to a particular corporate message cannot be obtained, remitting stockholders to individual speech on behalf of the business corporation will make such messages more difficult to utter. But the difficulty is lessened if the state requires that stockholders be given access to mailing lists and permits them, at their own expense, to solicit funds for particular messages. It is lessened further if the state allows management to use corporate facilities and assets to solicit funds for particular messages. It is lessened even further if those funds can be collected annually in advance for those political messages that management thinks will further corporate ends during the next year. Under such a plan, the obstacle to the utterance being made is no greater than if management were permitted to spend corporate funds on such messages but had to remit to claiming stockholders their pro rata share of those funds. See pp. 271-73 infra; cf. Abood v. Detroit Bd. of Educ., 431 U.S. 209, $240-42,240$ n.41 (1977) (dissenters to receive refund of their pro rata share of union's political expenditures). 
the interest of preserving the freedom of the individual investor to avoid contributing to speech he opposes, mechanisms exist that enable the state to curtail the power of individual investors to become a majority that can use a minority's funds for political speech, but still allow the majority to speak collectively, through Political Action Committees (PACs) or otherwise, outside the corporate structure. ${ }^{100}$

(b)

Economic theory, as well as political science, suggests a legitimate government interest in requiring stockholder consent for corporate political action. Allowing capital to be raised on the condition that its contributors permit management to use it for political purposes, without providing them a meaningful choice as to the particular political or noncommercial use, may increase the cost of capital. Most corporate decisions, particularly those affecting the profitability of normal business dealings in free markets, can only be effectively made and implemented if stockholders delegate to management decisonmaking power over the use of contributed funds. But when corporate power is to be exercised to affect governmental action, there is more reason to require express stockholder approval. In the first place, it is easier to seek advance stockholder consent for such action, which is not a matter of daily routine. In the second place, when the corporation uses funds to influence government action, the individual participant has given up more than simply control over the use of his contributed assets in effecting volitional market exchanges. To permit corporate funds to be used to influence the exercise of government power forces a person seeking profits from market transactions, for which he must delegate decisionmaking power, to relinquish power to determine the extent and character of governmental compulsion on himself and the rest of society. It fractures his power to influence government decisions, on a. range of issues-such as environmental or health and safety regulations, taxation, race relations, or the conduct of the nation's foreign affairs-that affect his welfare and that he may oppose. It also requires him to permit the use of his assets to support social views and generate social attitudes that may impinge upon his individual preferences.

"Bundling" such decisionmaking power-requiring investors to contribute to joint activity $\mathrm{XY}$, rather than permitting them to contribute to $\mathrm{X}$ activity and $Y$ activity separately - is inefficient by conventional economic

100. It has been suggested that, for many kinds of messages, only the corporation is able to generate and produce the necessary information. See Prentice, Consolidated Edison and Belloti: First Amendment Protection of Corporate Political Speech, 16 TULSA L. REV. 599, 636 (1981). Even if this were true, nothing would prevent the stockholders from organizing to acquire the information from the corporation and disseminating it at their own expense. 
analysis, unless the transaction costs of raising capital for $\mathrm{Y}$ exceed the increase in the cost of capital that results from the loss of potential contributors who choose not to contribute to $\mathrm{XY}$ because they wish to contribute to $\mathrm{X}$ activity or contingency but not to $\mathrm{Y} .{ }^{101}$ The transaction costs will undoubtedly exceed the savings from unbundling if every commercial or business operating decision is unbundled from the others and referred to the investors for individual choice. But such costs may well be less than the savings if only matters of political speech and social opinion are unbundled. ${ }^{102}$ Whether they will in fact be less depends upon how much more investors will seek to charge for their contributions if they perceive that their ability to affect the political or social consequences they favor is diminished by the fact that they must make joint contributions to $\mathrm{XY}$ rather than separate individual contributions. To require the state to allow only contributions to $\mathrm{XY}$ discourages certain contributors from investing in certain X's because of the compelled linkage with $Y$, and thus requires the state to raise the cost of capital. Since in many cases the savings may not be so clear as to make unbundling wise, the state need not require "unbundling." But its decision to do so may be a rational response to economic considerations, as well as an effort to enhance individual investors' power to make political choices. ${ }^{103}$

\section{The Proper First Amendment Balance}

If in authorizing the formation and operation of business corporations the government must choose between preserving the First Amendment in-

101. Given a choice between contributing to $X$ (for example, a "for-profit" shoe manufacturing venture) and/or contributing to $Y$ (for example, a venture organized to express views on government regulation of shoe imports, durability standards, and health standards), and contributing to XY (a single venture combining both efforts), some investors could rationally choose not to contribute to XY. Those persons would include at least those who believe that $Y$ 's activities, even if in support of $X$, can also produce government action that offends their personal preferences. They also would include those investors who believe the transaction costs of raising the funds for $\mathrm{Y}$ activity to be less than the savings in the cost of capital that result from separating contributions to $\mathrm{X}$ and $\mathrm{Y}$.

102. It does not materially alter the result that there will also be costs of identifying, and possibly debating, the matters to be unbundled.

103. The legislative decision may distinguish between political speech and speech addressed more broadly to matters of social policy that are not likely to become, or at least are not imminent, subjects of political action. The former may be defined as speech seeking to affect the exercise of the coercive power of the state on the individual investor-as by election of certain candidates or adoption of certain legislation-through action with respect to which the individual investor is given a voice by voting. The latter has fewer coercive implications for the individual, although it does affect social behavior that may produce constraints or pressure on individual behavior.

A legislature could rationally conclude that the individual investor should be protected against managerial or majoritarian corporate decisionmaking in matters that will produce government coercion but not in matters that have less coercive impact on him. The First Amendment may well prohibit such a distinction when the legislature seeks to restrict the individual's freedom of expression. But it need not preclude a legislature from making that distinction when the legislature seeks to enhance the individual investor's freedom of expression. See p. 276 infra. 
terests of individuals who from time to time constitute a minority of their stockholders and the similar interests of an equally transient majority of stockholders, how is the validity of its choice to be tested? Because legislation requiring stockholder consent for corporate political speech expands individuals' freedom to speak individually without precluding their freedom to band together to speak collectively, less exacting judicial scrutiny than the First Amendment otherwise requires may be appropriate in assessing the constitutional validity of such legislation. ${ }^{104}$ But to the extent that exacting scrutiny of the legislation is required to determine whether it is sufficiently narrowly drawn and whether it serves a sufficiently compelling government interest, nothing in the received learning makes such legislation invalid; and the teaching of cases involving union shop agreements ${ }^{105}$ suggests that it is valid.

Adumbrations from Buckley v. Valeo ${ }^{106}$ do not overshadow the legislation under discussion. The legislation does not prescribe a ceiling on the amount anyone can spend on speech, since each individual participant is free, acting alone or through a group formed for that end, to give as much as he chooses for political speech on behalf of the corporation or its purposes. Nor does it rest on the notion that the greater wealth and therefore the greater speech-making power of some individuals must be curbed in the interest of equalizing the relative ability or power of the voices of each individual in the political arena. ${ }^{107}$ It does deprive management of discretion, and transient majorities of control, over the funds of transient minorities. But it makes no systematic effort to restrain the speech of one identifiable class-like the wealthy in Buckley $v$. Valeo-more than that of another identifiable class of people, in order to equalize their voices.

Bellotti also does not address the questions here raised. That decision rests in part on the suspiciously narrow thrust of the statute ${ }^{108}$ and in part

104. Cf. Buckley v. Valeo, 424 U.S. 1 (1976) (Court did not require narrowest of strictures to achieve government purposes); CBS v. Democratic Nat'l Comm., 412 U.S. 94, 102-03 (1973) (judicial deference to congressional evaluation of competing First Amendment claims for broadcast media access). See also Craig v. Boren, 429 U.S. 190, 197 (1973); Rodriguez v. San Antonio Ind. School Dist., 411 U.S. 1, 98-110 (1973) (Marshall, J., dissenting); L. TRIBE, supra note 54, at 1082-89; Gunther, The Supreme Court, 1971 Term-Forward: In Search of Evolving Doctrine on a Changing Court: $A$ Model For a Newer Equal Protection, 86 HARV. L. REV. 1, 17-48 (1972). While the notion of deference to the legislative judgment has little place in the context of challenges to majoritarian restrictions on individuals' speech, efforts to protect individuals' interest in group utterances by requiring consultation with group members pose a somewhat different question for the Court. But cf. Karst, supra note 55, at 43-52 (presence of competing First Amendment claims in media access cases does not alter courts' obligation to assess interests).

105. E.g., $\Lambda$ bood v. Detroit Bd. of Educ., 431 U.S. 209 (1977); Brotherhood of Ry. \& S.S. Clerks v. Allen, 373 U.S. 113 (1963); International Ass'n of Machinists v. Street, 367 U.S. 740 (1961);

Railway Employees Dep't v. Hanson, 351 U.S. 225 (1956),

106. 424 U.S. 1 (1976).

107. See id. at $48-49$.

108. See note 35 supra. 
on the assumption that a flat prohibition of corporate political speech precludes anyone from uttering the proposed message on behalf of the corporation or its stockholders. ${ }^{109}$ The opinion scants the issues of the individual stockholders' freedom of expression and the availability of alternative stockholder-financed sources for the message; it also fails to address the question of what substitute for the managerial discretion that today's corporate laws allow would be constitutionally adequate to offset the impediment to corporate speech that a requirement of unanimous stockholder consent would create.

Similarly, neither the holdings nor the rationales of Consolidated Edison v. Public Service Commission ${ }^{110}$ and Central Hudson Gas \& Electric v. Public Service Commission ${ }^{11}$ preclude a requirement of stockholder consent for corporate political speech. The former case struck down an order of the New York State Public Service Commission prohibiting utility companies from including in their billing envelopes literature favoring the development of nuclear energy. The latter struck down an order by the Commission that sought to conserve energy by prohibiting utilities from engaging in promotional advertising. Neither case involved a claim of stockholders' rights under the First Amendment. In each case, the regulation was designed to protect the consumers and the public by denying them access to the content of the speech the utility was willing to make rather than to protect the rights of the stockholders to be free from compulsion to finance views they oppose. ${ }^{112}$

If the most immediately relevant cases do not preclude a requirement of unanimous stockholder consent, the teaching of other cases suggests that such a requirement can appropriately meet a compelling state need. The process for assigning weight to particular state interests in determining whether they are sufficiently compelling to offset particular impediments to speech is somewhat difficult to discern. How the Court balances the value of the protected interest and the burden the restriction imposes on First Amendment values remains a mystery comprehensible only to judi-

109. The opinion speaks of state action that "silence[s]" the speech or "suppress[es]" the message, so that it presumably cannot be offered to the world. First Nat'l Bank v. Bellotti, 435 U.S. 765,777 \& n.12 (1978).

110. 447 U.S. $530(1980)$.

111. 447 U.S. 557 (1980).

112. The Court's suggestion that the burden of supporting the utility's speech could be placed on stockholders, Central Hudson Gas \& Elec. Corp. v. Public Serv. Comm'n, 447 U.S. 557, 568 n.ll (1980), does not mean that the First Amendment requires the state expressly to do so or requires that shareholders bear the burden. Moreover, since the Court viewed the promotional literature in Central Hudson as "commercial" speech, id. at 566-68, it may have given less weight to stockholders' First Amendment rights than is appropriate when noncommercial speech is involved. In any event, in the Central Hudson case, as in Belloti, the Court equated the state's action with the "complete suppression of speech." Id. at 569-71. 
cial initiates. ${ }^{113}$ The same may be said for determining overinclusiveness or underinclusiveness under First Amendment criteria. But if we were to test a state requirement of unanimous stockholder approval by the usual criteria prescribed for testing restrictions on communication that are not directed at a particular message but that incidentally affect the process of communicating-whether the restrictions further a sufficiently "compelling state interest," are sufficiently "narrowly drawn," and are the "least restrictive" of the available alternatives-it would pass that test, at least as developed in decisions of cognate questions involving labor unions.

The necessary compelling state interest is to be found at least in the need to protect individual stockholders against being forced to choose between contributing to political or social expressions with which they disagree or foregoing opportunities for profitable investment. ${ }^{1{ }^{14}}$ The Court's cases upholding the rights of union members not to contribute to political speech made by the union suggest that this interest justifies the balance of competing First Amendment rights of stockholders that the proposed legislation strikes. ${ }^{15}$ In those cases, the Court required unions that were statutorily authorized to negotiate union shop agreements (or to require workers who did not wish to join the union to make payments equivalent to dues) to offer some appropriate form of rebate to those workers who did not desire their contributions to be spent on efforts to achieve political results that they did not favor.

The sacrifice of the employee's First Amendment freedom of association under the statutory union shop and exclusive bargaining provisions up-

113. Compare Bates v. State Bar, 433 U.S. 350 (1977) (interest in assuring lawyers' professional conduct not sufficiently compelling to justify ban on advertising) with Friedman v. Rogers, 440 U.S. 1 (1979) (interest in non-deceptive trade name use sufficiently compelling to justify prohibition on practicing optometry under trade name) and Ohralik v. Ohio State Bar Ass'n, 436 U.S. 447 (1978) (interest in proper conduct of legal profession sufficiently compelling to uphold disciplinary action against lawyer for in person solicitation of clients in personal injury suit). The process is equally unclear when First Amendment associational rights are involved. Compare Kusper v. Pontikes, 414 U.S. 51 (1973) (binding voters, in later primary election, to choice of party in earlier primary violates right of free association) with Rosario v. Rockefeller, 410 U.S. 752 (1973) (statute requiring registration of party affiliation 30 days before election does not violate voters' associational rights). Some of the teaching on the "intermediate review" standard, see note 104 supra, suggests that the balancing process should, or may, be more deferential to the legislature than usual when two sets of First Amendment interests are in conflict. Cf. CBS v. Democratic Nat'l Comm., 412 U.S. 94, 102-03 (1973) (judicial deference to congressional balancing of competing First Amendment rights of broadcast media access). But see Karst, supra note 104, at 48 (courts should not defer to legislatures but must themselves balance competing First Amendment interests in media access cases).

114. Neither Consolidated Edison nor Central Hudson suggests that this interest is less than compelling. In Consolidated Edison the Court avoided the cognate, but different, issue of the compelled support by ratepayers of views with which they disagree, while in Central Hudson the Court found commercial speech rather than political speech to be involved. See note 112 supra.

115. See Abood v. Detroit Bd. of Educ., 431 U.S. 209 (1977); Brotherhood of Ry. \& S.S. Clerks v. Allen, 373 U.S. 113 (1963); International Ass'n of Machinists v. Street, 367 U.S. 740 (1961); Railway Employees Dep't v. Hanson, 351 U.S. 225 (1956). 
held in Railway Employees Department v. Hanson ${ }^{116}$ is no less an intrusion on the individual than is the restriction of the majority's right of expression under a requirement of unanimous stockholder consent. Indeed, to deny to private participants the power to condition the entitlement of other private individuals to join with them in commercial ventures on the latter yielding control of their funds for political purposes imposes a less significant loss of First Amendment interests on the former than laws authorizing union shops require of workers. It is hard to find criteria by which to measure whether the government's compelling interest in authorizing union shops in order to facilitate union organization by preventing free riders is more compelling than its interest in protecting the individual investor's freedom of speech and enhancing his freedom of political choice. But the Court's opinions in Hanson, International Association of Machinists v. Street, ${ }^{117}$ and Brotherhood of Railway \& Steamship Clerks v. Allen ${ }^{18}$ suggest that protecting the individual from being "forced" to contribute to political speech he opposes responds to a more important First Amendment concern than is offended by "forcing" him to join or support a particular union. ${ }^{19}$

In Abood v. Detroit Board of Education, ${ }^{120}$ the Court found unconstitutional a state law permitting a regime in which the leadership of a state employees' union with a union shop agreement required contributions from minority members for political speech, even when made in the legitimate interest of the union and its majority. Perhaps the Constitution does not, of its own force, protect individual workers' interests in their own freedom of expression against similar arrangements by unions that do not (and by law cannot) have union shop agreements. ${ }^{121}$ But if the state wishes to support those individual workers' interests, the considerations impelling the conclusion reached in Abood point to the constitutional suf-

116. 351 U.S. 225 (1956).

117. 367 U.S. 740 (1961).

118. 373 U.S. 113 (1963).

119. See 373 U.S. $113,118-23$ (1963); 367 U.S. $740,756-70$ (1961); 351 U.S. $225,236-38$ (1956).

120. 431 U.S. 209 (1977).

121. Compare Reid v. McDonnell Douglas Corp., 443 F.2d 408, 410-11 (10th Cir. 1971) (union shop clause authorized by National Labor Relations Act not sufficient government involvement to support First Amendment suit by dissenting employees) with Linscott v. Millers Falls Co., 440 F.2d 14, 16-17 (1st Cir.), cert. denied, 404 U.S. 872 (1971) (consensual union shop statute sufficient federal action to support suit by employee dismissed for refusing to contribute to union political fund on religious grounds) and Seay v. McDonnell Douglas Corp., 427 F.2d 996, 999-1001 (9th Cir. 1970) (alleged improper use of agency fee required from non-union employees can confer federal jurisdiction under federal unfair labor practices laws). Variations in union-employer bargaining arrangements may vary the applicability of the First Amendment's prohibition of union expenditure of dues for political purposes. See Comment, supra note 86 , at $416-20$. 
ficiency of that state effort to limit the powers of the leadership or of a majority of the members to use the union till so to express themselves. ${ }^{122}$

The constitutional interest in protecting the individual's right to speak, or his right not to have his funds used to promote views with which he disagrees, may be less compelling for stockholders seeking to make investments than for workers seeking jobs. In form, consenting in advance to the political use of their funds is as voluntary when individuals invest in a corporation as when they accept employment in a union shop. They are not required by law to invest or to accept such employment. The investor is as free to sell his investment as the worker is to leave his job. But in substance, the freedom to refrain from working is not equally as exercisable as the freedom to refrain from investing, because the worker's alternatives are not as fungible as the investor's alternatives, and because the cost of seeking alternatives is greater for the worker than for the investor. ${ }^{123}$ Nevertheless, in either case, consenting in advance to the use of funds for expression on an infinity of subjects cannot realistically be characterized as voluntary. If most companies would "bundle" the power to make political and economic decisions, as is likely in the absence of government prohibition, ${ }^{124}$ the freedom of investors to go elsewhere would be costly, if not wholly illusory. ${ }^{125}$ Moreover, exercise of the freedom to "exit"126 would leave the investor's enterprise free to use his previously contributed funds for the very political purposes he finds offensive. Hence, whether or not the First Amendment forbids a state from conditioning access to investments on the same onerous terms that it forbids a state from conditioning access to jobs where union shops prevail, the First Amendment interests of investors offer comparable support for a state regulation forbidding private parties from so conditioning access to investments. ${ }^{127}$

122. The fact that constitutional prohibitions may not reach private arrangements-even arrangements the law tolerates-does not frustrate the power of the state to offer protection for members against such otherwise permissible arrangements.

123. CF. Cort v. Ash, 422 U.S. 66, 81 \& n.13 (1975) (early corrupt practices legislation evinced greater concern for union members than for shareholders since former more likely to be coerced into membership).

124. See Comment, The Constitutionality of the Federal Ban on Corporate and Union Campaign Contributions and Expenditures, 42 U. CHI. L. REV. 148, 156-57 (1974).

125. This suggests that the union shop configuration is a more apposite analogy than union requirements that members yield political rights in "right-to-work" states. But see First Nat'l Bank v. Bellotti, 435 U.S. 765, 794 n.34 (1978) (suggesting latter is more apt analogy).

126. See id. (shareholder "free to withdraw his investment at any time"). But exit may be difficult for pension fund or other fund beneficiaries.

127. Cf. Associated Press v. United States, 326 U.S. 1, 20 (1945) (private parties may not combine to exclude others from publishing). That both state and federal governments have long tolerated, indeed authorized, political action by union leadership and corporate management using collective funds without consultation with stockholders or members does not preclude this conclusion. But see Bolton, supra note 3 , at 413 (past legality of corporate and union political activity undermines state interest in protecting individual freedom of expression of group members). The requisite compelling state interest need not be "necessary" to the state's survival. It is sufficient, particularly when each 
If a compelling state interest is found, the question remains whether the means of furthering that interest is the "least restrictive means," or is sufficiently "narrowly drawn." 128 The concept of "least restrictive means" requires a degree of restrictiveness appropriate for the level of effectiveness sought in the regulation. Applying the concept, therefore, involves striking the right balance of protectiveness and restrictiveness by comparing at the margins the degree of protection the regulation offers the protected interest with the extent of the deprivation of speech the regulation imposes. The indeterminacy of the process belies the apparent rigor of the formula. ${ }^{129}$ Application of the formula is particularly puzzling in the present context, which pits the protection of individuals' First Amendment rights to refrain from supporting speech against the public's First Amendment interest in the exchange of views and opinions. Does the least restrictive of the alternatives mean the narrowest protection of speakers consistent with the broadest protection of the public, or does it mean the narrowest intrusion on the audience's interest consistent with the broadest protection of speakers' rights? If the answer is somewhere in between, how should a court determine where?

Decisions like Hanson, Street, Allen, Pipefitters Local No. 562 v. United States, ${ }^{130}$ and $A b o o d$ cast some light on the appropriate balance. ${ }^{131}$ They imply that permitting the creation of the union's treasury by checkoffs from union dues and allowing political use of that treasury subject to rebates to dissenting members, or creating separate segregated funds made up of voluntary contributions solicited by use of corporate funds, would adequately protect union members' or stockholders' rights. But these prescriptions do not mean that the Constitution forbids the government from offering greater protection for such individuals. ${ }^{132}$

competing interest may arguably claim to further the aspirations embodied in the First Amendment, that the state has chosen to act with a goal that reflects a basic or substantial interest and has chosen a means that closely "fits" that goal. The number of investors involved is substantial, and while the number of potential dissidents can only be estimated, it is far from trivial. See notes 13 \& 14 supra.

128. See Consolidated Edison Co. v. Public Serv. Comm'n, 447 U.S. 530, 540-43 (regulation restricting speech must be "precisely drawn"); cf. Buckley v. Valeo, 424 U.S. 1 (1976) (requiring lessthan-strict scrutiny).

129. See Ely, Flag Desecration: A Case Study in the Roles of Categorization and Balancing in First Amendment Analysis, 88 HARV. L. REV. 1482, 1484-90 (1975); Gunther, Reflections on Robel: It's Not What the Court Did But the Way That It Did It, 20 STAN. L. REV. 1140, 1147-48 (1968); Note, Less Drastic Means and the First Amendment, 78 YALE L.J. 464 (1969).

130. 407 U.S. 385 (1972).

131. See also Consolidated Edison Co. v. Public Serv. Comm'n, 447 U.S. 530, 543 (1980) (intimating that excluding the costs of bill inserts from the rate base might be acceptable method of balancing competing interests).

132. The constitutional requirement of proration ordered in those cases did not reject-nor does it logically preclude-a legislative judgment that the appropriate remedy was a requirement of unanimous membership consent. The courts repeatedly emphasize the constitutional concern that union members' political contributions be entirely voluntary. See Pipefitters Local No. 562 v. United States, 407 U.S. 385, 427 (1972); Brotherhood of Ry. \& S.S. Clerks v. Allen, 373 U.S. 113, 118 (1963); 
One means of providing greater protection would be to require a separate segregated fund, to be raised only by stockholder solicitation of contributions from others, rather than to allow political use of corporate assets and subsequent pro rata rebates to dissenting stockholders. So long as stockholders are free to use their own money and facilities to raise such a fund for political speech, a requirement of unanimous stockholder consent to each and every corporate utterance of political speech would not offend the First Amendment, even though it would effectively prohibit political speech by the corporation. On that premise, the most the government need assure to stockholders is access to stockholder lists so that they may themselves raise separate segregated funds for political purposes. It is not necessary to authorize management's use of corporate funds to solicit and administer contributions from stockholders for PACs in the manner the Federal Election Campaign Act authorizes. ${ }^{133}$

Such an arrangement for a separate segregated fund protects the minority against non-volitional contributions more effectively than does a

United States v. Boyle, 482 F.2d 755, 760-64 (D.C. Cir.), cert. denied, 414 U.S. 1076 (1973); FEC v. National Educ. Ass'n, 457 F. Supp. 1102 (D.D.C. 1978). But cf. International Ass'n of Machinists v. Street, 367 U.S. 740, 772 (1961) (suggesting impropriety of a blanket prohibition of such union expenditures); Comment, Regulation of Labor's Political Contributions and Expenditures: The British and American Experience, 19 U. CHI. L. REV. 371, 385-88 (1952) (questioning similarly categorical restrictions on union political expenditures).

133. 2 U.S.C. $\$ 441 \mathrm{~b}(\mathrm{~b})(2)(\mathrm{C})(1976)$ (permitting expenditure of corporate and union funds for "the establishment, administration, and solicitation of contributions to a separate segregated fund to be utilized for political purposes"). See Vandegrift, The Corporate Political Action Committee, 55 N.Y.U. L. REV. 422, 456-58 (1980); Comment, Corporate Political Action Committees: Effect of the Federal Election Campaign Act Amendments of 1976, 26 CATH. U.L. REV. 756 (1977). While the use of corporate funds and facilities to create and operate segregated political funds appears to be common, see Budde, The Practical Role of Corporate PAC's in the Political Process, 22 ARIz. L. REV. 555 (1980); Mayton, Politics, Money, Coercion, and the Problem with Corporate PACs, 29 EMORY L.J. 375, 387 (1980), such use is itself an abuse of the assets of those stockholders with views opposed to the purposes of the segregated fund. Moreover, it gives management an advantage in the process of fund raising that is denied to opposing stockholders and that is not justified by the fact that it is a familiar allocation of advantages and disadvantages in the proxy area. The fact that stockholder volition in making contributions is not as easily coerced as employee volition, see Mayton, supra, at 382-85, does not lessen the government's interest in denying management a role in the PAC. In any event, whether or not anything in the First Amendment precludes giving management such control over PACs, it is difficult to see what entitles management, or even a majority of stockholders, to be able to retain that control in the face of a legislative choice to let stockholder efforts solve the entire matter. Indeed, the phenomenal growth of corporate PACs suggests that stockholders' assets are being used quite extensively to finance the creation, maintenance, and operation of the segregated funds by management.

It has been suggested that gifts by corporate PACs have simply substituted for individual gifts by businessmen and corporate executives, or have furnished a mechanism to legalize formerly illegal gifts by corporations. See Epstein, Business and Labor Under the Federal Election Campaign Act of 1971, in PARTIES, INTEREST GROUPS, AND CAMPAIGN FINANCE LAwS 107, 140-41 (M. Malbin ed. 1980); Malbin, Of Mountains and Molehills: PACs Campaigns and Public Policy, in PARTIES, INTEREST GROUPS, AND CAMPAIGN FINANCE LAWS, supra, at 152; Malbin, Neither a Mountain Nor $A$ Molehill, 3 REG., May/June 1979, at 41. Whether or not the suggestion is accurate, the First Amendment should not hamper the government's efforts to forbid corporate assets from underpinning corporate PACs, unless those efforts selectively discriminate on the basis of the content of particular corporate speech. 
scheme of rebates. The latter requires the individual to incur the cost of making the claim to obtain a return of funds, and to risk revealing the political views with which he disagrees, ${ }^{134}$ rather than simply to refrain from revealing his preferences and from contributing funds in his possession in response to the solicitation. ${ }^{135}$ In the case of widely dispersed stockholders who can readily liquidate their investment, those considerations are of considerable significance. ${ }^{136}$ Allowing such aggregative action outside the corporate structure satisfactorily accommodates both the rights of the minority not to yield their First Amendment entitlements to the majority and the rights of the latter to act collectively to amplify their speech entitlements. ${ }^{137}$

That accomodation, moreover, does not "[burn] down the house to roast the pig."138 The public's interest in the potential content of corporate speech does not require maturing that potential by any more government assistance than is necessary to enable the stockholders to organize themselves for conveying such messages without the use of corporate assets. The societal interest in the receipt of the messages no more prohibits government from protecting investors against having to support the purveyance of views they oppose than it requires them to support corporate

134. See Abood v. Detroit Bd. of Educ., 431 U.S. 209, 241 (1977) (dissenting union member need only express general opposition to ideological expenditures, since to require greater specificity would violate his freedom to hold beliefs without public disclosure); L. TRIBE, supra note 54, at 589 n.5.

135. But cf. Pipefitters Local 562 v. United States, 407 U.S. 385, 414-15 (1972) (concern whether contributions by union members to segregated fund are "voluntary").

136. Such stockholders may well be induced to sell their securities rather than to claim rebates for the political use of their funds. Government protection against the transaction costs, including income tax costs, of claiming a pro rata share of political expenditures reasonably requires a rule of unanimous consent, particularly if the amount of the payment is less than the cost of getting it. The ease with which the investor can opt out, by selling his stock, compared to the cost of seeking his rebate may make such protection more appropriate for investors than for union members, whose level of participation in such matters in the union is apt to be more intense. Moreover, pension fund beneficiaries may be unable to opt out, or feasibly to be given rebates.

137. It is difficult to find anything in the Constitution that requires the majority's interest in avoiding the transaction costs of organizing separately to be favored over the minority's interest in avoiding the transaction costs of seeking rebates.

138. United States v. UAW, 352 U.S. 567, 596 (1957) (Douglas, J., dissenting). Bellotti purports to distinguish $A b o o d$ 's premises, in part on the ground that the remedy in $A b o o d$ did not preclude the leadership-that is, the majority-from expressing itself through use of the union treasury; it merely required a rebate of the minority's funds. See First Nat'l Bank v. Bellotti, 435 U.S. 765,794 n.34 (1978). See also United States v. CIO, 335 U.S. 106, 149-50 (1948) (Rutledge, J., concurring). But rebate is not the only permissible mode of vindicating dissenters' rights; indeed, the Constitution supports greater protection for stockholders, see note 132 supra, in order to assure them of volition comparable to the extensive assurance of volitional behavior required for union dissenters. See Pipefitters Local 562 v. United States, 407 U.S. 385, 414-15 (1972). The Supreme Court has noted that the union leaders' discretion under a rebate scheme calls for clear efforts to protect the employee's freedom not to dedicate his funds to political issues. Hence, it is appropriate to require an arrangement that imposes on the union the burden of computing and giving effective notice of members' entitlements. See Brotherhood of Ry. \& S.S. Clerks v. Allen, 373 U.S. 113, 122 (1963); International Ass'n of Machinists v. Street, 367 U.S. 740, 775 (1961). 
waste. ${ }^{139}$ In sum, although a rebate scheme may be a permissible accommodation of all the relevant interests in the corporate context, a legislative judgment that the voluntary contribution arrangement is preferable is not constitutionally offensive.

\section{Political Speech, Commercial Speech, and Beyond}

The conclusion that the First Amendment permits the government to preclude delegation of the power to spend corporate funds on political speech to corporate management or to mere majoritarian stockholder decision does not end the inquiry. Assuming that the state does not wish to subject all corporate speech-political, commercial, and other-to a requirement of shareholder consent, may it restrict some kinds of corporate speech in a different manner than it restricts other kinds?

Vindication of individual stockholder's First Amendment rights does not require the government to impose a stockholder consent requirement either for all corporate speech or for none. Differential regulation of corporate political speech and corporate commercial speech is constitutionally permissible if, as the Court has stated, commercial speech is entitled to a lower level of protection under the First Amendment than is "political" speech. ${ }^{140}$ In addition, as we shall see, the cost of giving stockholders protection for the former may be much greater than for the latter. Hence, it is far from self-evident that the First Amendment requires the same consensual arrangements among stockholders for corporate commercial speech that it permits, and indeed supports, for corporate political speech.

\section{A. The Distinction Between Political and Commercial Speech}

To acknowledge the permissibility of differential treatment of political, commercial, and possibly other categories of speech implies that the outer boundaries of political speech are determinable. This in turn raises the

139. Nor does the First Amendment require that corporations be permitted to contribute to or expend funds on behalf of the many trade associations engaged in political activity or the molding of public opinion. Cf. 93 CONG. REC. 6438-39 (1947) (testimony of Senator Taft suggesting that corporations would be prohibited under Taft-Hartley Act from contributing to trade associations that in turn made political contributions). But cf. Citizens Against Rent Control/Coalition for Fair Housing v. City of Berkeley, 102 S. Ct. 434 (1981) (\$250 limit on contributions to committees formed to influence public referenda violates First Amendment). That the First Amendment permits management to make political and charitable contributions does not mean that it requires that management be authorized to make them. Cf. California Medical Ass'n v. FEC, 101 S. Ct. 2712 (1981) (\$5000 limit on annual contributions by individuals and unincorporated associations to multicandidate political committees does not violate First Amendment).

140. See Metromedia, Inc. v. City of San Diego, 101 S. Ct. 2882, 2891-92 (1981); Central Hudson Gas \& Elec. Corp. v. Public Serv. Comm'n, 447 U.S. 557, 562-63 (1980); Ohralick v. Ohio State Bar Ass'n, 436 U.S. 447, 455-56 (1978). 
question whether such determinations can be made with sufficient precision to meet constitutional standards.

It may be argued that it is impossible to define impeded speech as "political speech" without violating the stricture against government interference with the "content" of speech. The neutrality that the Supreme Court has required of government regulation of speech seems to prohibit any and all differential treatment based upon the content of speech, or even upon its subject matter. ${ }^{141}$ While the Court appears to have retreated from the rigor of that prohibition when obscenity is singled out for regulation, ${ }^{142}$ the centrality of political speech to the democratic process ${ }^{143}$ makes the Court's mandate most rigorous when legislation curtails political speech. Nevertheless, in a number of circumstances the Court has upheld the singling out of political speech for a particular restriction not applicable to other kinds of speech. ${ }^{144}$ Although the criteria applied in those decisions are not entirely clear, a fair reading of the cases suggests that the proposals under consideration here satisfy those criteria.

In the majority of these cases, the Court held that the government was entitled to refrain from offering, or from requiring others to offer, to political speakers facilities made readily available to cultural or commercial speakers. The governmental interests thought sufficiently important to permit political speakers to be denied access to a relevant medium of communication in these cases ${ }^{145}$ are different from those involved in the effort to preserve shareholders' individual rights of expression or of refraining from expression. ${ }^{146}$ But it is hard to identify considerations that make those interests any more "compelling," particularly when so vindicating individual shareholders' rights does not deny the communication to listeners, and its only cost is to require those groups of shareholders who wish to speak collectively to do so outside the corporate structure. ${ }^{147}$ Assuming,

141. See Carey v. Brown, 447 U.S. 455 (1980); Linmark Assocs. v. Township of Willingboro, 431 U.S. 85 (1977); Erznoznik v. City of Jacksonville, 422 U.S. 205 (1975); Police Dep't v. Mosely, 408 U.S. 92 (1972).

142. See Young v. American Mini Theatres, Inc., 427 U.S. 50 (1976); cf. Snepp v. United States, 444 U.S. 507 (1980) (secrecy clause in former CIA employee's employment contract enforceable).

143. See First Nat'l Bank v. Bellotti, 435 U.S. 765, 776-77 (1978): Buckley v. Valeo, 424 U.S. 1, 14-15 (1976); Mills v. Alabama, 384 U.S. 214, 218-19 (1966); New York Times Co. v. Sullivan, 376 U.S. 254, 266 (1964); T. EMERSON, supra note 54, at 7.

144. See, e.g., Greer v. Spock, 424 U.S. 828 (1976); Lehman v. City of Shaker Heights, 418 U.S. 298 (1974); cf. Red Lion Broadcasting Co. v. FCC, 395 U.S. 367 (1969) (upholding FCG requirement that licensees provide right of reply to persons who are subject to verbal "personal attacks").

145. See Greer v. Spock, 424 U.S. 828, 838 (1976) (business of a military installation is "to train soldiers, not to provide a public forum"); Lehman v. City of Shaker Heights, 418 U.S. 298, 304 (1974) (permitting political advertising would jeopardize long-term commercial advertising, subject users of the buses and trolleys "to the blare of political propaganda," and create "lurking doubts about favoritism").

146. See also Miami Herald Publishing Co. v. Tornillo, 418 U.S. 241 (1974); CBS v. Democratic Nat'l Comm., 412 U.S. 94 (1973).

147. See, e.g., Lloyd Corp. v. Tanner, 407 U.S. 551, 566-67 (1972); Cammarano v. United 
therefore, that it is permissible to single out corporate political speech for regulation, the question remains whether a constitutionally satisfactory line can be drawn between political speech and other corporate speech.

Although the inquiry touches upon "protected speech," in the present context judicial scrutiny less exacting than the demands of First Amendment due process, such as "intermediate" review ${ }^{148}$ or a "rational basis" standard, may appropriately test the line to be drawn between political and other types of speech. If the line were designed to separate protected political speech from less protected commercial speech ${ }^{149}$ in order to prevent undue restriction of the former, the process would appropriately require "exacting scrutiny"-a "clearly drawn" line that is "least restrictive" for its purpose. But if the corporation's political speech may be impeded to the extent necessary to protect shareholders' freedom of speech, the relaxation of that impediment by eliminating the restriction on nonpolitical speech should not require the clarity of statement or tightness of coverage that might otherwise be appropriate. ${ }^{150}$ On that premise, a "substantial basis" for the regulatory effort would leave some play in the joints, and so long as the proscription gives adequate notice to those it governs, a satisfactory line can be drawn.

The narrowest definition of political speech-as Buckley v. Valeo ${ }^{\text {s1 }}$ suggests-is speech expressly urging or opposing the election of particular candidates, ${ }^{152}$ or the adoption of particular rules of law by legislatures, administrative agencies, or courts. But communication need not be explicit to have the same effect in encouraging the election or defeat of candidates or the adoption or repeal of governmental policies. ${ }^{153}$ Considerations underlying the First Amendment urge a broad view of such implicit political speech when the object is to facilitate self-government and to protect mi-

States, 358 U.S. 498, 513 (1959). But cf. Miami Herald Publishing Co. v. Tornillo, 418 U.S. 241, 251 (1974) (right of reply statute struck down despite impossibility of entry into print media). That speech may be uttered elsewhere or by someone else is, in itself, no justification for a government restriction on, or aimed at, content or subject matter. See L. TRIBE, supra note 54 , at 603 . But that principle does not apply with equal power to government efforts to protect the First Amendment interests of individuals in order to prevent them from being forced to speak against their will. Id. at 604.

148. See note 104 supra.

149. Compare First Nat'l Bank v. Bellotti, 435 U.S. 765 (1978) (striking down regulation that singled out particular political speech for less protection) with Metromedia, Inc. v. City of San Diego, $101 \mathrm{~S}$. Ct. 2882 (1981) (striking down regulation that separated particular commercial speech from less protected commercial and political speech).

150. Cr. Farber, Content Regulation and the First Amendment: A Revisionist View, 68 GEo. L.J. 727, 747-48 (1980) (government regulation of speech should be constitutional if inter alia it is sufficiently closely related and limited to legitimate goal).

151. 424 U.S. 1 (1976).

152. Id. at $43-44$.

153. See note 22 supra. But of. FEC v. AFSCME, 471 F. Supp. 315 (D.D.C. 1979) ("Pardon Me" poster illustrating Nixon pardon does not express advocacy). See also Bolton, supra note 3, at 419-22. 
norities' rights in the governmental process against majoritarian restriction. ${ }^{154}$ The same considerations urge an equally broad definition of political speech when the object is to protect individual investors against being required to permit use of their assets to support corporate speech dictated by management or by a mere majority of the stockholders.

Those considerations suggest that a definition of political speech should include at least conventional "issue" advertising or "advocacy" advertising designed to condition public opinion along particular policy or ideological lines. The questions, for example, whether government intrusion into scientific research by universities, or whether private rather than governmental pursuit of new sources of energy is socially or economically desirable are within the ambit of political speech. So too are discussions of regulatory pressures that contribute to high prices, of the reasons for inflation, or of the public interest in the reinvestment of unusually high profits. ${ }^{155}$ The effect, not to mention the intent, of such communications is to influence public opinion on matters of government policy. ${ }^{156}$ The fact that such speech may be a more remote cause of governmental action than more explicit requests for such action ${ }^{157}$ does not lessen the need-or the entitlement-of members of a group to protection against being forced to support, by such speech, political views they oppose. Thus, whether or not the political speech to be protected is as broad as Meiklejohn suggests, ${ }^{158}$ there is every reason to make the circle of protected speech large.

Indeed, there is reason to offer protection beyond even broadly defined political speech to all matters of opinion. The Supreme Court has pointed

154. See A. MEIKLEJOHN, FREE SPEECH 1-27 (1948) (First Amendment derives from "basic American agreement that public issues shall be decided by universal suffrage"); Meiklejohn, The First Amendment is an Absolute, 1961 SUP. CT. REV. 245, 256-57; note 143 supra. But cf. BeVier, The First Amendment and Political Speech: An Inquiry into the Substance and Limits of Principle, 30 STAN. L. REV. 299 (1978) (First Amendment protects only speech that participates in processes of democratic government and does not advocate or incite unlawful acts); Bork, Neutral Principles and Some First Amendment Problems, 47 IND. L.J. 1, 24-35 (1971) (First Amendment protects only explicitly political speech discussing government).

155. See, e.g., IRS Hearings, supra note 10, at 583-989 (illustrating variety of such ads); P. SETHI, supra note 10, at 21-52, 138-78 (same). Unlike traditional image advertising, "advocacy advertising" is concerned with "the propagation of ideas and elucidation of controversial social issues of public importance in a manner that supports the position and interests of the sponsor while expressly denying the accuracy of facts and downgrading the sponsor's opponents." Id. at 7. See also Sethi, Issuc-Oriented Corporate Advertising: Tax Treatment of Expenditures, 19 CAL. MAN. REV. 5 (1976) (distinguishing among types of advertising for purposes of deductibility of expenses); Comment, supra note 19, at 647-67 (discussing advocacy advertising by insurance companies seeking to affect outcome of jury verdicts in automobile negligence cases).

156. See P. SETHI, supra note 10, at 1-72.

157. Cf. Buckley v. Valeo, 424 U.S. 1, $42-43$ (1976) (distinction between advocacy of issues and advocacy of particular candidates often dissolves in practice); Cammarano v. United States, 358 U.S. 498, 504-05 (1959) (refusing to distinguish between legislative lobbying and advertising made to influence public referenda for purposes of tax deductibility).

158. Meiklejohn, The First Amendment is an Absolute, 1961 SUP. CT. REV. 245, 256-63; Wellington, On Freedom of Expression, 88 YALE L.J. 1105, 1110-21 (1979) (discussing Meiklejohn). 
out that whether the views expressed concern social questions, matters of aesthetics or literary quality, human behavior in general, or the condition of the universe, the government cannot force people to support views they do not hold. ${ }^{159}$ This teaching argues for the constitutional validity of government efforts to prevent private groups from forcing members to pay for publishing opinions or general views on "matters of public concern"160 that they oppose, and from conditioning the opportunity to invest in commercial enterprises on agreeing to such payments.

The essential problem, then, is not how large or how small the circle of protected speech should be, but how to define its boundaries in order to give adequate notice of the requirement imposed. The problem is difficult because an item of speech can combine political matters, commercial matters, and matters of opinion on subjects having nothing to do with political or commercial matters; the solution may therefore require disentangling the political or commercial component from the others. But to the extent that the government's interest is in protecting investors from being forced to contribute to the utterance of views that they oppose, the teaching of Hanson and Abood suggests the possibility of a constitutionally acceptable path through the tangle. In those cases, the Court made a constitutional distinction between funds spent for "collective bargaining, contract administration, and grievance-adjustment purposes," and funds spent for "political and ideological purposes unrelated to collective bargaining." "161 Abood also recognized that some speech falls clearly into neither category, ${ }^{162}$ and thus that " $[\mathrm{t}]$ here will . . . be difficult problems in drawing lines between collective-bargaining activities, for which contributions may be compelled, and ideological activities unrelated to collective bargaining, for which such compulsion is prohibited."163 Nevertheless, the Court in Abood was able to identify a constitutionally tolerable distinction.

The corporate analogue to "collective bargaining, contract administration, and grievance adjustment" is the conduct of corporate business, including the offering of goods or services for sale. Under that analogy, government can require unanimous stockholder consent for the expenditure of any corporate funds for "political" purposes, ${ }^{164}$ or for any communication

159. See West Virginia State Bd. of Educ. v. Barnette, 319 U.S. 624, 642 (1943) (no one should be made to subscribe to government prescribed orthodoxy "in politics, nationalism, religion, or other matters of opinion").

160. Village of Schaumburg v. Citizens For A Better Environment, 444 U.S. 620, 635 (1980).

161. Abood v. Detroit Bd. of Educ., 431 U.S. 209, 232 (1977). See International Ass'n of Machinists v. Street, 367 U.S. 740, 764, 769 (1961).

162. Abood v. Detroit Bd. of Educ., 431 U.S. 209, 236 (1977).

163. Id. (footnote omitted).

164. Singling out corporate "political" contributions for special treatment has a long history. See, e.g., N.Y. ELEC. LAW § 14-116 (McKinney 1978); notes 3, 16, \& 17 supra. 
to the public ${ }^{165}$ that does not merely offer the corporation's services or products for sale or solicit offers to buy its products or services, or that does "more than propose a commercial transaction." 166 There should be no greater difficulty in drawing this line in a manner consistent with the First Amendment than is present when distinguishing between expenditures for the operation of union business and union expenditures for political purposes.

To be sure, the same communication may serve a general business purpose-like improving the image of the corporation as a public-spirited, socially responsible enterprise or as a reliable and innovative provider of products or services-and at the same time advocate views of general social or political import. Alternatively, it may both offer a specific commercial transaction and explicitly enunciate views on general social or political issues. But the formulation of a prescription that separates, with adequate notice, speech requiring stockholder consent from speech not requiring it is no more difficult than separating commercial from noncommercial speech. Existing doctrine currently requires precisely such a separation in order to apply the different levels of judicial review to the different levels of government regulation that the Constitution authorizes for commercial and noncommercial speech. ${ }^{167}$

To conclude that the state may effectively separate corporate political speech from corporate commercial speech does not address the question of whether some forms of corporate political speech may be regulated differently from others. For example, does the premise of protecting the stockholder's First Amendment rights permit the state to require shareholder consent for grass roots campaigns, but not for direct presentations by corporate representatives to congressional committees or to Congress? ${ }^{168}$ Does

165. The prohibition could include communications on public matters to shareholders, employees, customers, or suppliers. See IRS Hearings, supra note 10, at 76-141.

166. Virginia State Bd. of Pharmacy v. Virginia Citizens Consumer Council, 425 U.S. 748, 771 n.24 (1976) (quoting Pittsburgh Press Co. v. Pittsburgh Comm'n on Human Relations, 413 U.S. 376, 385 (1973)).

167. See Metromedia, Inc. v. City of San Diego, 101 S. Ct. 2882, 2889-92, 2896 (1981); Central Hudson Gas \& Elec. Corp. v. Public Serv. Comm'n, 447 U.S. 557, 562-66 (1980); Village of Schaumburg v. Citizens For A Better Environment, 444 U.S. 620 (1980); cf. Bates v. State Bar, 433 U.S. 350, 380-81 (1977) (overbreadth doctrine less applicable to commercial than political speech); Fed. Com. Comm'n, Fairness Doctrine and Public Interest Standards, 39 Fed. Reg. 26372, 26380-84 (1974) (fairness doctrine should be applied differently to editorial and commercial advertising); Bird, Goldman \& Lawrence, Corporate Image Advertising: A Discussion of the Factors that Distinguish Those Corporate Image Advertising Practices Protected Under the First Amendment From Those Subject to Control by the Federal Trade Commission, 51 J. URB. L. 405 (1974) (distinguishing "image" ads from commercial ads). See also National Comm'n on Egg Nutrition v. FTC, 570 F.2d 157 (7th Cir. 1977), cert. denied, 439 U.S. 821 (1978) (upholding prohibition on false advertising concerning health impact of cholesterol).

168. Compare I.R.C. $\$ 162$ (e) (allowing deduction for business expenses incurred for appearance before legislative committees or communication with legislators with respect to legislation of direct interest to the taxpayer but not for participation in political campaigns) with 40 CONG. REC. 96 
it allow a requirement of shareholder consent for radio and television political ads but not for similar ads in the print media, or for political action on the state or local level but not on the national level (or vice versa)?

In general, regulation of "subject matter," and certainly of "content," is properly viewed as forbidden. ${ }^{169}$ But this does not necessarily imply that the First Amendment requires either that all forms of corporate political speech must be subject to stockholder consent or that no forms of such speech may be. Constitutionally valid distinctions can be made among different media or forms for the expression ${ }^{170}$ of political speech in the present context. The long-standing distinction between grass roots campaigns and legislative appearances, for example, has a persuasive claim to constitutional validity. ${ }^{171}$ On the other hand, many other distinctions may not be constitutionally tolerable. The statute involved in Bellotti, for example, may have been aimed at a kind of speech that was so particular that neither the premise of protecting stockholder First Amendment rights nor any other legislative goal was adequate to justify so special a restriction. ${ }^{172}$

It is beyond the scope of this article to determine, or even to examine, the lines that may properly be drawn. But there is reason to doubt the necessity for invoking the conventional jurisprudence of First Amendment due process to test the propriety of such lines. The government action to be assessed does not restrict the rights of individuals to speak. Rather, it seeks to restrict the rights of individuals to apply private economic pressure on others to contribute to the former's speech. Collective speech through the corporation is thus curtailed, but it is available through parallel group action by stockholders. Such an array of competing claims on First Amendment values does not generate the same questions that direct restrictions on individual speech pose. Hence, distinctions among such restrictions may appropriately be tested by less exacting scrutiny-at least when the restrictions are not aimed at the particular content of

(1905) (Roosevelt message to Congress arguing that any corporate expenditures on legislation should be unlawful except those for counsel hired for legal services).

169. See note 141 supra.

170. The impermissibility of distinctions based upon content need not afflict distinctions based on form or mode of expression. See L. TRIBE, supra note 54, at 693-700; Bollinger, Freedom of the Press and Public Access: Toward a Theory of Partial Regulation of the Mass Media, 75 MICH. L. REV. 1, 22-24, 32-37 (1976); Farber, supra note 150; Schauer, Categories and the First Amendment: A Play in Three Acts, 34 VAND. L. REv. 265, 285-96 (1981). See also FGG v. Pacifica Found., 438 U.S. 726, 748-50 (1978); Capitol Broadcasting Co. v. Mitchell, 333 F. Supp. 582, 584-86 (D.D.C. 1971), afrd, 405 U.S. 1000 (1972); Note, Advertisements for Contraceptives as Commercial Speech in the Broadcast Media, 31 CASE W. RES. L. REV. 336, $341-43$ (1981).

171. See note 168 supra. But cf. Note, Grassroots Lobbying and the Public's Right to Hear: First Amendment Implications of I.R.C. Section 162(e)(2)(B), 2 CARDOZO L. REV. 597 (1981) (grassroots lobbying "a vital form of political speech").

172. See First Nat'l Bank v. Bellotti, 435 U.S. 765, 793 (1978). 
speech $^{173}$-than is required for testing the validity of direct restrictions on individuals' speech. ${ }^{174}$

\section{B. Government Regulation of Corporate Commercial Speech}

The considerations that make a requirement of stockholder consent for corporate political speech compatible with the First Amendment are less evident when other forms of speech are considered, such as commercial speech or "cultural" speech. Indeed, with respect to commercial speech, ${ }^{175}$ the result is curiously problematic.

The problem arises in part because of the need, which bringing commercial speech under the First Amendment emphasizes, to fashion regulatory distinctions based upon the differing content or subject matter of the speech. In the resulting hierarchy of values, less protection is available for commercial speech than for political speech; it is possible that still another, intermediate, level of protection may be appropriate for speech that is too far removed from social action or opinion to be characterized as political and yet too remote from business or commercial transactions to be characterized as commercial. ${ }^{176}$ But wherever any particular speech may rank in the hierarchy, there is no doubt that, under the cases, commercial speech is entitled to less protection than political speech. ${ }^{177}$

The lower value thus assigned to commercial speech creates an apparent anomaly when the regulatory effort rests on the need to protect shareholders' rights under the First Amendment. To impose the same consent requirement for each corporate commercial ad as for each corporate political utterance is to rest the regulation on the need to protect the individual stockholder's interest in a corporate communication that concerns the wholly volitional exchange transactions for which he made his investment. But a state could fairly conclude that the investor's interest in such speech is entitled to no more protection against delegation of authority to management than is his interest in the commercial transaction itself. So long as the corporation's speech is neither political nor concerned with other

173. If the distinction between speech for which stockholder consent is required and speech for which it is not is based solely on the content of the particular speech, its propriety merits First Amendment review, as it would if the government regulation directly prohibited a particular item of speech. While formally the regulation may be viewed as designed to prescribe the terms on which scattered investors may make business investments without yielding their First Amendment rights, substantively, it should be viewed quite differently. Its purpose may be to make one message less easily communicable than another.

174. See note 104 supra.

175. An example would be a requirement of stockholder consent for advertising campaigns for sales to minors or for particular kinds of ads even though no legal restriction were imposed on sales of cigarettes.

176. See p. 286 infra.

177. See note 167 supra. 
matters of opinion with which the investor may have ideological or other normative disagreement, he has a less critical interest in preventing the "abuse" of his investment to finance the speech. Not only are the claims of individual investors for regulation of corporate commercial speech apt to be less compelling than those for regulating corporate political speech, but the cost to investors of restricting the former is apt to be much greater. Regulating corporate commercial speech reduces the likelihood that anyone will utter the communication more than does similar regulation of corporate political speech. For a state to require unanimous shareholder consent, or even prior consultation with stockholders, for particular commercial speech would interfere with the firm's day-to-day commercial operation on a vast variety of matters that are subject to an equally vast variety of views. ${ }^{178}$ Since the required consent could not be obtained rapidly enough for such daily commercial purposes, and since a separate fund for such purposes is impractical, ${ }^{179}$ any such requirement would effectively forbid commercial speech. Similar regulation of political-or possibly other noncommercial-speech by corporations would not have the same crippling effect.

These considerations imply that the First Amendment offers less support for, and a greater obstacle to, regulation of corporate commercial speech than corporate political speech. The apparent incongruity requires further analysis of the rationale for protecting commercial speech.

If the concept of commercial speech could be confined, in its import as well as in its terms, to nothing more than the offer of a commercial transaction, the mainspring for its protection under the First Amendment would be extracted. Thus defined, commercial speech would not rationally be entitled to protection under the First Amendment ${ }^{180}$ any more than is

178. As one author pointed out: "Probably all shareholders wish General Motors to prosper. Not all would wish to express the opinion that an Oldsmobile Cutlass is a great buy. Indeed, some shareholders certainly believe that General Motors should advertise more truthfully, some that it should advertise less truthfully, and some that it should not advertise at all." O'Kelley, supra note 30, at 1373.

179. While the creation of alternative PAC-like sources of funds may dilute the impact of the prohibition, the magnitude of the amounts to be solicited and the limited appeal of the solicitation might produce obstacles that are sufficiently onerous to make the requirement of stockholder consent testable as though it were a total suppression of commercial speech.

180. The First Amendment purports to distinguish speech (however interpreted) from other forms of behavior. It suggests, if it does not not compel, an offer of greater protection against government restrictions on the pursuit and communication of information and ideas, on debate over them and over political issues and social values, or on communicative entertainment, than on the purchase or sale of goods or other kinds of non-communicative behavior. See Wellington, supra note 158. The limits of the protection the First Amendment offers are uncertain, and may be sought in the definition of "speech" or by deriving from the language, structure, and purposes of the Constitution permissible functions or values speech may serve. In so determining its limits, there is little room for the protection of commercial transactions (not involving speech as a commodity) or of speech whose sole function is to facilitate such transactions. The Court in Virginia State Bd. of Pharmacy v. Virginia Citizens Consumer Council, 425 U.S. 748 (1976), justified bringing commercial speech under the First 
the language used in a contract or in a fraudulent representation, ${ }^{181}$ or than is the buy-sell transaction itself. ${ }^{182}$ But whatever regulation may be appropriate for such purely commer-

Amendment on the notion that society also may have a strong interest in the free flow of commercial information. Even an individual advertisement, though entirely 'commercial,' may be of general public interest. The facts of decided cases furnish illustrations: advertisements stating that referral service for legal abortions are available; that a manufacturer of artificial furs promotes his product as an alternative to the extinction by his competitors of fur-bearing mammals; and that a domestic producer advertises his product as an alternative to imports that tend to deprive American residents of their jobs. Obviously, not all commercial messages contain the same or even a very great public interest element. There are few to which such an element, however, could not be added. . . .

Moreover, there is another consideration that suggests that no line between publicly interesting' or 'important' commercial advertising and the opposite kind could ever be drawn. . . . So long as we preserve a predominantly free enterprise economy, the allocation of our resources in large measure will be made through numerous private economic decisions. It is a matter of public interest that those decisions, in the aggregate, be intelligent and well informed. To this end, the free flow of commercial information is indispensable. . . . And if it is indispensable to the proper allocation of resources in a free enterprise system, it is also indispensable to the formation of intelligent opinions as to how that system ought to be regulated or altered. Therefore, even if the First Amendment were thought to be primarily an instrument to enlighten public decisionmaking in a democracy, we could not say that the free flow of information does not serve that goal.

Id. at 764-65 (footnotes and citations omitted). While the argument in the latter paragraph is flawed, see Jackson \& Jeffries, Commercial Speech: Economic Due Process and the First Amendment, 65 VA. L. REV., 1, 14-18 (1979), the argument in the former paragraph remains troublesome-even if empirically there is reason to doubt that it has large import.

181. See Farber, supra note 67, at 384-91.

182. Viewed purely as a matter of commercial regulation, when the government constitutionally forbids a transaction, the First Amendment should not prevent the government from also forbidding a speaker from offering to engage in the transaction. Cf. Virginia State Bd. of Pharmacy v. Virginia Citizens Consumer Council, 425 U.S. 748, 772 (1976) (suggesting commercial ads could be banned if proposed transaction illegal). In that circumstance, the consumer's entitlement to be free of restrictions on offers does not rise above the speaker's right to offer. The notion that the First Amendment protects speech advocating violation of the law rests, at least in part, on considerations derived from the chilling effect such prohibitions may have on advocacy of changes in the law, and the value of initiating test litigation. See Wellington, supra note 158, at 1138-42. Those considerations, however, do not preclude foreclosing speech soliciting commercial transactions that the law forbids. As has been noted, commercial speech is less easily chilled than other speech. See note 89 supra. Hence, there is less reason to allow commercial speech soliciting the forbidden transaction in order to protect speech advocating repeal of the prohibition. Cf. NLRB v. Retail Stores Employees Local 1001, 447 U.S. 607, 614-15 (1980) (union prohibited from unlawfully picketing employer's customers); Bates v. State Bar, 433 U.S. 350, 384 (1977) (ads for illegal transactions may lawfully be suppressed); Pittsburgh Press Co. v. Pittsburgh Comm'n on Human Relations, 413 U.S. 376, 388 (1973) (publication of ads soliciting narcotics or prostitution could be forbidden). Whether the government should be able to forbid all public offers of or ads for transactions whose consummation it does not forbid presents a closer question. That it has long done so is plain. See Capital Broadcasting Co. v. Mitchell, 333 F. Supp. 582, 583-86 (D.D.C. 1971), affd, 405 U.S. 1000 (1972) (ban on cigarette advertising on radio and television); 15 U.S.C. $\S 1335$ (1976) (same); 18 U.S.C. $\$ 1304$ (1976) (ban on broadcasting lottery ads); UTAH CODE ANN. $\$ \S 32-7-26$ \& 32-7-28 (1974) (advertising or soliciting orders for alcholic beverages prohibited). See also Packer Corp. v. Utah, 285 U.S. 105 (1932) (ban on billboard tobacco advertising not denial of equal protection). To be sure, even in the regulation of commercial affairs the Constitution does not assure that the greater power always includes the lesser. But an otherwise unchallengeable ban on offers for the sale of commercial goods whose sale the government could constitutionally forbid should not offend the First Amendment merely because the government seeks to discourage, rather than prohibit, the sale transaction. 
cial speech, most corporate speech typically contains both commercial and noncommercial elements. Any given commercial speech may contain more than merely an offer of a commercial transaction; it may also have implicit political or social import, ${ }^{183}$ or may be cast in language or symbols that please or enrich the listener in ways that are too remote from matters of opinion or social concern to be called political. The political impact or the pleasure and enrichment the viewer receives from the "cultural" aspects of the communication, both of which are within the reach of the First Amendment, may be quite independent of any influence on the viewer's decision to accept or reject the proposed commercial transaction.

Nothing in the Supreme Court's opinions on the subject helps to determine which of these types of speech any particular commercial utterance embodies. Indeed, the Court's decision to bring commercial speech under the protection of the First Amendment rested in part on the Court's stated inability to determine when speech is "merely" commercial and when it has broader import of the kind the First Amendment attempts to protect. ${ }^{184}$ Under that rationale, if the state may require stockholder consent for corporate political speech, it may also require stockholder consent for corporate speech in which the commercial is not extricable from the political. Of course, such a requirement may impose an intolerable burden on corporate commercial activity. But it is not necessary to impose such a burden in order to protect stockholders' First Amendment interests in political or noncommercial speech.

Although it may, the state is not required to give the same protection to the stockholder's interest in corporate political speech when the political message is part of commercial speech as when it is not part of commercial speech. Since the state is not obliged to protect the stockholder by a consent requirement, the high cost of such a requirement is sufficient constitutional justification for not imposing it on corporate commercial speech. The state may choose to require stockholder consent for corporate com-

183. See, e.g., Central Hudson Gas \& Elec. Corp. v. Public Serv. Comm'n, 447 U.S. 557, 579-81 (1980) (Stevens, J., concurring); Linmark Assocs. v. Township of Willingboro, 431 U.S. 85, 92-98 (1977); Bigelow v. Virginia, 421 U.S. 809, 820-21 (1975); cf. Village of Schaumburg v. Citizens for A Better Environment, 444 U.S. 620, 628-32 (1980) (commercial and informative messages intertwined in solicitations for funds). See also Prentice, supra note 100, at 654; Rotunda, The Commercial Speech Doctrine in the Supreme Court, 1976 U. ILL. L.F. 1080. If the social or political aspects of commercial utterance were explicit and separable from the commercial aspects, regulation of only the former but not the latter aspects by requiring investor consent would not burden corporate business operations.

184. Virginia State Bd. of Pharmacy v. Virginia Citizens Consumer Council, 425 U.S. 748, 76465 (1976). See also Baker, supra note 97, at 42 n.146 (discussing attempts to define commercial speech); Kaufman, The Medium, the Message and the First Amendment, 45 N.Y.U. L. REV. 761, 769 (1970) (frequently difficult to separate commercial speech and protected speech). But cf. Jackson \& Jeffries, supra note 180, at 19-25 (improper to abandon distinction between commercial and political speech merely because it may be difficult to draw in some cases). 
mercial speech that has political import only when it finds that the cost is not prohibitive. For example, the state appropriately may (or may not) require such consent when the speech takes the form of advocacy advertising even if it also contains an express offer of products or services for sale on specified terms. Although not a simple matter, drawing an appropriate line between commercial speech that can thus be regulated and commercial speech that cannot is no more difficult than drawing a large variety of valid regulatory distinctions in economic affairs based on estimates of cost differentials. ${ }^{185}$

In any event, there is reason to allow the state to regulate corporate commercial speech even if it declines to regulate corporate political or other noncommercial speech. The essential justification for bringing commercial speech within the First Amendment is its noncommercial import. ${ }^{186}$ Without that import, commercial speech is nothing more than part of a buy-sell transaction, for which the First Amendment is irrelevant. If the government may decline to protect stockholders with respect to the noncommercial import of corporate commercial speech, ${ }^{187}$ such a declination should not subject the government to any greater restrictions on its power to regulate commercial speech than if it had not declined. Regulation of corporate commercial speech in the interest of consumers and the public should not encounter the same First Amendment obstacles as does similar regulation of the commercial speech of individuals. ${ }^{188}$ Unlike individuals, business corporations have no "expressive" interest in noncommercial speech; thus, the purely commercial aspect of corporate commercial speech can be viewed as simply a commercial matter. ${ }^{189}$ Unless the state's regulation can be seen as improperly selective in its impact on the

185. A number of cases suggest that such distinctions have a place in the regulation of commercial speech even if not in the regulation of political speech. See, e.g., Metromedia, Inc. v. City of San Diego, 101 S. Ct. 2882, 2896 (1981); Central Hudson Gas \& Elec. Corp. v. Public Serv. Comm'n, 447 U.S. 557, $579-81$ (1980) (Stevens, J., concurring); Friedman v. Rogers, 440 U.S. 1, 11-16 (1979). It does not detract from this conclusion that the Metromedia plurality held that, because noncommercial speech is entitled to heightened First Amendment protection, a government decision not to proscribe commercial speech in certain circumstances constitutionally precludes proscription of noncommercial speech in those same circumstances. Here, the values associated with commercial and political speech are "inverted." Since government power over corporate speech is exercised to protect First Amendment values for stockholders, and since protection of noncommercial speech is less costly than protection of commercial speech, the teaching of Metromedia does not preclude the differential regulation contemplated here. $C f$. Lehman v. City of Shaker Heights, 418 U.S. 298, 304 (1974) (upholding prohibition on political but not commercial ads on city buses).

186. See note 180 supra.

187. The government is not obliged to require a corporation that places magazine ads offering a product for sale to obtain prior stockholder approval for the ads, even if their message has a noncommercial import that stockholders might oppose.

188. But of. p. 267 supra (discussing cases).

189. In such circumstances, the audience's interest under the First Amendment rises to no higher entitlement than the speaker's capacity to speak. See pp. 244-47 supra. 
noncommercial aspects of the speech, ${ }^{190}$ the regulation should be substantially removed from the ambit of the First Amendment.

It can be argued that if the only basis for the state's power to regulate any corporate speech is to protect stockholders' First Amendment rights, then the state cannot regulate corporate commercial speech on some other basis-that is, in the interest of consumers or the public generally. This argument, however, pits First Amendment protection of commercial speech for its noncommercial import against the stockholder's opportunity to enjoy the protection of a state imposed consent requirement for corporate political or noncommercial speech. It implies that when a commercial tincture is added to corporate political speech stockholders lose the statutory protection to which they would otherwise be entitled. Expression of the concededly "less protected" category of speech becomes the basis for precluding statutory protection of stockholders' exercise of rights to expression of a "more protected" category of speech. The argument is a "peculiar inversion of First Amendment values." "So long as considerations of cost, or other neutral considerations having nothing to do with the First Amendment, impel the government to decline to exercise its power to protect stockholders' First Amendment interests in commercial speech, its regulation of that speech in the interest of consumers and the public should not become subject to constraints derived from the First Amendment. ${ }^{192}$

190. See Buckley v. Valeo, 424 U.S. 1, 293-94 (1976) (Rehnquist, J., concurring in part and dissenting in part); Karst, supra note 55, at 29-30.

191. Metromedia, Inc. v. City of San Diego, 101 S. Ct. 2882, 2895 n.18 (1981) (quoting John Donnelly \& Sons v. Campbell, 639 F.2d 6, 16 (1st Cir. 1980)).

192. In any event, even if the theory underpinning the constitutionality of a government requirement of stockholder consent for corporate political speech mandates a similar requirement when regulation of corporate commercial speech is proposed, a blanket requirement of consent for all commercial speech is not constitutionally mandated. Even when a proposed regulation of corporate commercial speech is grounded on stockholders' First Amendment rights, a case by case solution may be more appropriate than a categorical solution. On particular issues, such as advertising addressed to minors or the sale of certain drugs to anyone, the government may deem the product sufficiently dangerous and corporate exposure to liability from the ad sufficiently great to justify imposing a stockholder consent requirement, which will be valid as a protection of stockholders' rights. Indeed, a statute requiring prior approval by stockholders for ads or other communications carrying particular commercial messages, or requiring prior clearance of such messages with an administrative agency, could effectively regulate the commercial content of the message without creating First Amendment problems for the noncommercial aspects-if the regulation were otherwise neutral with respect to its noncommercial content. Notwithstanding that such an approach may make the "cases" distinguishable from each other only by reason of the commercial content of the communication, in any particular case the consent requirement may well pass muster as a regulation of commercial speech. See Metromedia, Inc. v. City of San Diego, 101 S. Ct. 2882, 2894-95 (1981). Of course, First Amendment standards applicable to commercial speech must then test any statute that seeks to regulate commercial speech that stockholders have approved. 


\section{Government Regulation of Corporate Cultural Speech}

Some forms of speech that are neither commercial nor political can conveniently be characterized as "cultural"-such as speech that is embodied in scientific discussion, artistic production, creative expression, or entertainment ${ }^{193}$ that is too remote from social action or normative opinions to be treated as political. Corporations may engage in such speech, without either political or commercial coloration, when they support concerts, theatrical performances, television shows, or the like. If such support can be called speech, the question of obtaining stockholder consent for it resembles the question of consent asked with respect to political speech.

Although the case for permitting a requirement of stockholder consent for purely "cultural" expression is less compelling than for political speech, ${ }^{194}$ it is not at odds with either the language or the import of the First Amendment to let the state define the terms on which corporations can ask individual investors to consent to corporate cultural speech. Protecting the investor's freedom not to be forced to contribute to expositions he opposes may legitimately permit the state to entitle him to make invest-

193. See, e.g., Schad v. Borough of Mt. Ephraim, 101 S. Ct. 2176 (1981) (live entertainment); Southeastern Promotions, Ltd. v. Conrad, 420 U.S. 546 (1975) (theatrical performance); Bantam Books, Inc. v. Sullivan, 372 U.S. 58 (1963) (books); Joseph Burstyn, Inc. v. Wilson, 343 U.S. 495 (1952) (motion pictures); Goldberg, The Constitutional Status of American Science, 1979 U. ILL. L.F. 1, 2-16 (science).

194. The varied considerations said to justify First Amendment protection of speech carry different imperatives. Many commentators have urged that free speech is essential to the functioning of the political process in a democratic society that elects its governors. See A. MEIKLEJOHN, FREE SPEECH (1948); Bork, supra note 154, at 23. Others have added the importance of untrammeled discussion as a necessary safety valve for a stable political order. See T. EMERSON, supra note 54, at 7 . Possibly a less compelling imperative, but one affecting a considerably broader range of communications, is the vindication of the personal autonomy of individual citizens, whether in expressing themselves, receiving the communications of others, or exchanging ideas. See Baker, supra note 88; Scanlon, $A$ Theory of Freedom of Expression, 1 PHIL. \& PUB. AFF. 204, 215-22 (1972). A still different consideration is the social interest in the pursuit of truth and the enrichment of the mind and spirit of mankind, which cannot be optimally met when speech and inquiry are trammeled.

Of these considerations, the concern for personal autonomy may support First Amendment protection of communication that does no more than offer to exchange goods or services in a commercial transaction. In addition, of course, many offers of such exchanges carry with them communication that fulfills the other functions the First Amendment protects. To the extent that only matters of personal autonomy are involved, some justification is required to hold that the speaker or listener is entitled to a higher level of protection against government regulation in order to facilitate his enrichment from communication than to facilitate his enrichment from the purchase or sale of material goods or services. Whether or not such a justification can be found apart from the First Amendment, the freedom of speech clause is not focused on speech merely facilitating commercial transactions. See note 180 supra. In any event, when there is a social interest in the speech, whether for political purposes, see A. MEIKLEJOHN, supra, at 27; Bork, supra note 154, at 26 , or for the advancement of truth, see J. MILL, ON LIBERTY 9-32 (People's ed. 1873); Milton, Areopagitica, reprinted in THE TRADITION OF FREEDOM 3, 3-32 (M. Mayer ed. 1957), a different and possibly more compelling case can be made for the need for protection against governmental restriction. Moreover, to the extent that governmental attacks on "nonpolitical" ideas are historically associated with conditions that produce repression of political speech, it may be appropriate to accord each type of expression the same protection, and both more protection, than commercial speech, which is not generally associated with similar political repression. 
ments on terms that do not require him to yield his preferences as a patron of the arts or entertainment to corporate management or to his fellow stockholders. Corporate sponsorship of cultural performances may be less likely to collide with investors' preferences in such affairs than corporate statements of social opinions or of political views. Nevertheless, there is a residue of protectable investor speech that would justify a state in requiring him to be given a voice in its utterance, or at least an uncluttered choice not to contribute to it.

No less important, a requirement of individual investor approval of corporate cultural speech would not impose on the listening world the same obstacles to receipt of the message as would such a requirement for purely commercial speech. The occasions for such cultural speech are not so frequent or so unpredictable as to require prompt corporate decisions. Moreover, stockholders acting on their own, albeit collectively, can generate funds for such performances in a fashion comparable to Political Action Committees. Individual stockholder contributions to a separate fund for such purposes may not be materially less likely than are contributions for political speech, ${ }^{195}$ and are significantly more likely to be made than are contributions for purely commercial speech.

In sum, although corporate cultural speech is not as clearly a matter for reference to the individual stockholder's choice nor as likely to be supported by stockholders acting apart from the enterprise as is political speech, it is not so far removed from the latter that comparable treatment should be denied. It is not in any event a matter on which a court can say, at least without evidence on the likelihood of stockholder action apart from the corporation, that the state's interest in preserving the individual investor's choices is not sufficient to permit a prohibition of corporate cultural expenditures in the absence of stockholder consent.

\section{Corporate Speech as One Form of Corporate Behavior}

To conclude that the First Amendment does not preclude government regulation of corporate commercial speech and that it does indeed support prohibition of corporate political speech or even corporate cultural speech on less than unanimous stockholder consent does not mean that there is no constitutional protection for expression by business corporations. It merely assimilates all types of corporate speech with other kinds of corporate behavior, and subjects the regulation of speech to the same constitutional criteria that restrict regulation of other corporate activities.

195. If there is any significant difference in the likelihood of such funds being raised, the state might choose to permit use of corporate offices and facilities to raise and manage the funds for cultural, but not political, purposes. 
In a world in which corporate enterprise receives from government both costly restrictions on, and substantial gifts to, its profitmaking capacity, the corporation's ability to use its assets to influence government may well be an aspect of corporate property rights. To what extent the government may limit corporate capacity to seek to influence government for corporate benefit presents a problem of property for the corporation, but of political liberty for its stockholders. For an individual seeking government action in order to obtain economic benefits for himself, these economic and political rights may be inseparable, and the individual's economic preferences may benefit from any protection the Constitution accords to the individual's political rights; alternatively, the individual's economic preferences may be modified because of the noneconomic goals he chooses. A business corporation, however, cannot legitimately pursue noneconomic goals, and unlike an individual, its economic preferences and political power are feasibly separable. The state thus may seek, in support of the individual stockholder's First Amendment interests, to restrict the corporation's political activity. The question of the extent to which the state may thus validly impose restrictions on the corporation's "property" rights is to be answered by reference not to the First Amendment, but to other constitutional provisions. By the same token, if corporate speech is regulated differently from other kinds of corporate conduct, or if different types of corporate speech by business corporations are regulated differently, the exacting scrutiny the First Amendment demands need not measure the validity of those regulatory differences, unless they conceal a hidden agenda or some particular message is singled out for regulation because of its content. ${ }^{196}$

\section{Peripheral Considerations}

A proposal to forbid only business corporations from engaging in noncommercial speech without stockholder consent raises two other significant problems: first, whether a constitutionally satisfactory line can be drawn around business enterprises that are not engaged in the communications business, and second, whether such a regulation may constitutionally be confined to business corporations and not be extended to other enterprises.

196. To the extent that the statute in Bellotti singled out for prohibition not merely a particular form of corporate political speech (referenda) but also a unique instance of that form (referendum on a graduated income tax), it might properly have raised a question under the equal protection clause, entirely apart from the First Amendment. See Nimmer, The Meaning of Symbolic Speech Under the First Amendment, 21 U.C.L.A. L. REV. 29, 39-42 (1973). 


\section{A. Enterprises in the Communications Business}

The first question arises because of the possible constitutional distinction between the validity of a stockholder consent requirement for speech by commercial corporations not engaged in the communications business and such a requirement for newspaper or media corporations. The freedom of individuals to band together, in corporate form or otherwise, to communicate with others derives from First Amendment protection of free speech and freedom of the press. ${ }^{197}$ As we have seen, First Amendment considerations imply limits on the state's power to regulate internal decisionmaking in those associations or communications enterprises, but those limits need not restrict government regulation of such decisionmaking in normal business enterprises. ${ }^{198}$

It is not difficult to draft a regulatory statute that covers an automobile company or a railroad but not a newspaper enterprise or an association organized to affect public opinion and government action. Drawing the line between solely commercial advertising agencies and trade journals may pose a more difficult problem, and it may be improper to try to differentiate between trade assocations formed for business purposes and other associations. ${ }^{199}$ But whatever may be the difficulties at the margin, in general the distinction between communications businesses, which are anchored in activities that First Amendment press and association rights protect, and other businesses can be articulated in regulatory legislation.

More substantial problems arise, as the Chief Justice pointed out in Bellotti ${ }^{200}$ when dealing with hybrids, like outdoor advertising companies or conglomerates that include both a commercial venture like a steel company and a publication such as a daily newspaper, or that couple a soft drink vendor with a broadcasting station or motion picture exhibitor. ${ }^{201}$ If a media corporation's stockholders are constitutionally protected against a requirement of supermajority consent for the corporation's speech, but the stockholders of a steel company or soft drink vendor are entitled to benefit

197. See, e.g., Citizens Against Rent Control/Coalition for Fair Housing v. City of Berkeley, 102 S. Ct. 434. 437-38 (1981); Buckley v. Valeo, 424 U.S. 1, 22 (1976); NAACP v. Button, 371 U.S. 415, 428 (1963); NAACP v. Alabama, 357 U.S. 449, 460 (1958); T. EMERSON, supra note 54, at 432; L. TRIBE, supra note 54 , at $700-08$.

198 See notes 87 \& 89 supra.

199. Whatever may be the rights of trade associations and their individual members under the First Amendment, see Swillinger, Federal Regulation of the Campaign Finance Activity of Trade Associations-An Overview, 29 EMORY L. J. 395 (1980), they need not include a right to receive corporate contributions made without stockholder consent. But $c f$. Citizens Against Rent Control/ Coalition for Fair Housing v. City of Berkeley, 102 S. Ct. 434 (1981) (limit on contributions to committees formed to influence public referenda violates First Amendment). Whether the due process clause requires a different result is another question.

200. See First Nat'l Bank v. Bellotti, 435 U.S. 765, 796 (1978) (Burger, C.J., concurring).

201. E.g., Metromedia, Inc. v. City of San Diego, 101 S. Ct. 2882, 2886 (1981) (billboards for commercial and noncommercial speech). 
from such a requirement, a problem of separation is posed. Should a newspaper or periodical otherwise entitled to First Amendment protection against a supermajority consent requirement become subject to greater restriction on its utterances if it is a division of a steel company? Alternatively, should the stockholders of a steel company lose their entitlement to the protection of a statutory consent requirement if the company acquires a newspaper?

On one premise, when an investor becomes a stockholder in a steel company with a newspaper division, he assumes the risk that he will have his funds used for political speech he opposes, just as if he had decided to become a stockholder of an enterprise that was only a newspaper company. ${ }^{202}$ Under that view, the government may no more require his consent for anything published in the newspaper in the former case than in the latter. On a contrasting premise, however, the state could eliminate the risk that an investor's funds will be used for political speech he opposes by subjecting publishing corporations that are parts of nonmedia conglomerates to the same requirements of stockholder consent for publication that apply to other commercial corporations. Investors in non-affiliated publishing ventures would retain First Amendment rights unlimited and unprotected by a stockholder consent requirement, while investors in publishing enterprises affiliated with commercial ventures would not retain such unlimited rights. Investors in nonpublishing ventures would not be exposed to the risk-through acquisition of a media enterprise-of losing the First Amendment protection of a consent requirement, while investors in publishing ventures would lose their possible First Amendment entitlement to simple majority rule only if a sufficiently large number of them sold their shares to give control of the corporation to a nonpublishing business. ${ }^{203}$

It is possible to avoid choosing between those two premises by requiring stockholder consent for political speech only by the non-media corporation or division of the conglomerate. But speech by the newspaper subsidiary or division urging government policies that favor the steel business might constitute evasion of the requirement of obtaining consent from stockholders of "the" corporation for political speech by the steel company. A possible solution for such evasion-if it is evasion-may be found by analogy to the distinction drawn in Buckley v. Valeo between "truly" independent expenditures and those "controlled by or coordinated with the candi-

202. This is true whether he bought stock of a steel company that later began to publish a newspaper or bought stock of a steel company that already published a newspaper.

203. To be sure, this would obstruct a source of equity financing (i.e., conglomerates) for publishing ventures. Whether doing so would restrict speech to an extent that cannot adequately be offset by other equity financing raises questions that require further inquiry. 
date."204 Legislation could provide that in order for the media division of an enterprise to be free of a stockholder consent requirement, that division must be publishing a bona fide publication of general circulation, not merely a trade "give-away." The definitional problem is not without its difficulties, but the distinction drawn in Buckley $v$. Valeo suggests that they may be overcome.

\section{B. Trade Unions and Other Associations}

Particularly in view of the emerging First Amendment jurisprudence of underinclusiveness, ${ }^{205}$ the question remains whether remitting corporations to the alternatives of stockholder consent for noncommercial speech or collective action by contribution outside the corporate structure is constitutionally offensive unless a similar requirement is imposed upon all other associations, particularly trade unions. There is good reason to distinguish between unions and large, publicly held business corporations, both in terms of how their assets are generated and distributable, and how their members vote for leadership and generally relate to the enterprise. ${ }^{206}$ Perhaps the constitutional entitlement of union members in union shops to be relieved of the obligation to pay for union expression of political views they oppose implies constitutional permission for states to offer similar protection to all union members by law. If so, the only significant question is whether the particular techniques of relieving members of such payment obligations may differ among different kinds of organizations. Specifically, if proration of expenditures for political speech is permissible among unions, is a different approach-prohibition of collective speech without stockholder consent-a permissible technique for protecting stockholders of business corporations? Similarly, if a union-financed PAC is authorized, may a corporate-financed PAC be prohibited?

Both unions and publicly held corporations promote the economic interests of their members and stockholders. But a great deal more is involved in union membership than in investment in a publicly held corporation, in terms of both exit capacity and participation in common social and educational activities. A rebate or proration process may be appropriate for a member of a group that is often largely local and engages its membership in active participation, where voting is by the person rather than by the

204. 424 U.S. 1, 46 (1976). See Comment, Independent Political Committees and the Federal Election Laws, 129 U. PA. L. REv. 955 (1981).

205. See First Nat'l Bank v. Bellotti, 435 U.S. 765, 793 (1978).

206. See Lambert, note 2 supra, at 1049-50; Rauh, Legality of Union Political Expenditures, 34 S. Cᄉl. L. REV. 152, 162 n.49 (1961); Comment, Of Politics, Pipefitters, and Section 610: Union Political Contributions in Modern Context, 51 TEX. L. REV. 936, 981-83 (1973); Comment, supra note 132 , at 387 . 
share, and from which exit is not easy. ${ }^{207}$ On the other hand, the remoteness of passive, dispersed, and essentially transient investors from the decisionmaking process of a publicly held corporation may justify a government's conclusion that the protection of a consent requirement coupled with a stockholder-managed separate fund, rather than a rebate system, is required in order to safeguard adequately the investor's political "rights." 208

Apart from any questions concerning what distinctions in the treatment of corporations and unions are permissible, the Court in Bellotti regarded as fatal defects the failure of the statute to distinguish between large and small or publicly held and privately held corporations, and its failure to cover non-corporate "entities or organized groups in which numbers of persons may hold an interest or membership, and which often have resources comparable to those of large corporations."209 Constitutionally valid distinctions can readily be drawn between publicly held corporations and privately held enterprises. Whether the line is that defined by federal securities laws, by various state law definitions of close corporations, by the fact of listing on a national securities exchange, or otherwise, existing laws illustrate a range of constitutionally unchallengeable distinctions that permit statutes to protect investors in publicly held ventures in ways that investors in "private" enterprises do not need because they can protect themselves. ${ }^{210}$ These laws furnish adequate ground for suitable distinctions to be made to protect stockholders under the First Amendment.

Whether or not the suggestion in Bellotti that a judgment to cover publicly held corporations cannot constitutionally be made without also covering publicly held real estate partnerships, ${ }^{211}$ business trusts, or some vaguely suggested "other associations" is meant as a real distinction, legislation covering all for-profit enterprises (whether corporate or not) that fit

207. See Comment, The Regulation of Union Political Activity: Majority and Minority Rights and Remedies, 126 U. PA. L. REV. 386, 411 (1977).

208. That a rebate scheme may be more suitable for unions than for corporations is also suggested by differences in the financial consequences of such a scheme-with respect, for example, to the tax consequences to investors or infeasibility to pensioners of receiving the rebate and the difficulty that a separate segregated fund, in lieu of union dues, might cause for unions. See International Ass'n of Machinists v. Street, 367 U.S. 740, 771 (1961); Beck v. CWA, 468 F. Supp. 93 (D. Md. 1979) (ordering restitution of fees union improperly collected); Ball v. City of Detroit, 84 Mich. App. 383, 269 N.W.2d 607 (1978) (ordering payment of union dues into escrow account during lawsuit); Sullivan, Freedom of Association and the Public Sector Agency Shop: Ball v. Detroit and $\Lambda$ bood v. Detroit Board of Education, 85 Dick. L. REV. 21, 46-47 (1980).

209. First Nat'l Bank v. Bellotti, 435 U.S. 765, 793 (1978). See Bolton, supra note 3, at 414-15.

210. In private corporations the distorting effect of the proxy system in favor of non-owning management is minimal, and stockholders are able to participate in decisionmaking or to contract more realistically for restraints on the use of their assets by management or by majorities.

211. A state could make the rational judgment that real estate syndications tend to involve sophisticated investors seeking tax shelters, who can look after themselves better than stockholders of lesser sophistication who invest in corporations without tax-shelter bait. 
a "publicly held" description can avoid its thrust. Notwithstanding suggestions to the contrary, ${ }^{212}$ large publicly held corporations may also readily be distinguished from nonprofit enterprises and from "special interest" groups, whether they have large treasuries and represent special economic interests, like the chamber of commerce, the AMA, or the aerospace trade association, or whether they are less sectarian and less well-financed groups like the Natural Resources Defense Council. To the extent that such enterprises are organized for the purpose of exercising the very speech the First Amendment seeks to protect, they may well be entitled to different treatment in such matters than are business corporations. ${ }^{213}$ Furthermore, to the extent that their form contemplates voting by members rather than by economic weight, a less compelling case can be made for protection of dissenters than in the case of the business corporation. ${ }^{214}$ While the matter may yield a different conclusion on further inquiry, such as a requirement that distinctions be drawn by mode of member voting rather than by the nonprofit category, nothing that commentators have said or that the Court has opined requires, under the First Amendment, the equal protection clause, or otherwise, that strictures on speech applied to business corporations be equally applied to all collectives or groups. Of course, if choices are made to subject some nonprofits but not others to strictures applicable to business corporations, serious questions might arise. But nothing in the received learning or the analysis of commentators requires "special interest" PACs to be subject to the same restrictions that may be applied to corporate PACs.

\section{Conclusion}

It is not the purpose of this article to prescribe a legislative program to regulate corporate political activity or corporate speech-whether political, commercial, cultural, or otherwise. The effort, rather, is to establish that with respect to publicly held business corporations not engaged in the communications business, the First Amendment does not preclude a government requirement of stockholder consent that may effectively prohibit either some or all noncommercial speech. To be sure, any program that seeks to delineate between political or noncommercial speech subject to a shareholder consent requirement and other speech not subject to such a

212. See Bolton, supra note 3, at 414-17.

213. See California Medical $\Lambda s s ' n$ v. FEC, 101 S. Ct. 2712, 2723-24 (1981); p. 260 \& note 89 supra.

214. Cf. Smith v. Higinbothom, 187 Md. 115, 48 A.2d 754 (1946) (suit by bar association members to prevent association from promoting election of political candidates dismissed); LaBelle v. Hennepin County Bar Ass'n, 206 Minn. 290, 288 N.W. 788 (1939) (bar association plebiscite on judicial nominees does not violate corrupt practices statute). 
requirement faces a difficult task of definition. But, notwithstanding problems at the margin, constitutionally valid lines can be drawn.

That a distinction between commercial speech and noncommercial speech is constitutionally feasible, indeed in some sense required, is an inescapable proposition. If the First Amendment permits a unanimous stockholder consent requirement to be imposed on the latter kind of corporate speech, it does so without at the same time requiring it to be imposed on the former. If the government opts not to protect stockholders, by declining to require their consent for the noncommercial import of corporate commercial speech, First Amendment considerations should not constrain its power to regulate corporate commercial speech in the interests of consumers and the public, at least where there is no suggestion that the regulation serves an improper hidden agenda.

The considerations discussed herein do not deny corporations other constitutional entitlements-for example, under the due process or equal protection clauses-with respect to corporate speech, or permit requirements of shareholder consent for such speech to be so onerous as to offend such constitutional provisions. ${ }^{215} \mathrm{But}$, in the absence of a suggestion of discriminatory treatment of particular content, the validity of restrictions that the government may impose on corporate speech in order to protect shareholders' First Amendment interests should not be subject to the most demanding standards of judicial review invoked under the First Amendment. Particularly with respect to corporate commercial speech, the First Amendment should not become the vehicle for restoring the lenses of the Lochner court to judicial scrutiny of economic regulation of either legislative or executive origin.

215. For example, a prohibition against officers testifying, without stockholder consent, before a legislative committee in support of or in opposition to legislation affecting the enterprise might be a denial of due process, as would such a prohibition against initiating or testifying in litigation. Perhaps, however, business corporations may be required to consult stockholders in matters left to the political process, such as legislation, even if they are not required to do so in matters relating to litigation. 


\section{The Yale Law Journal}

Volume 91, Number 2, December 1981

\section{David Wippman \\ Editor-in-Chief}

\author{
Randall Kennedy \\ Note \& Topics Editor \\ Richard Bartlett \\ George C. Harris \\ Robert Silver \\ George Wyeth \\ Note Editors
}

Ellen R. Porges

Managing Editor

Tim Atkeson

Russell Hayman

Jonathan R. Macey

Theodore A. Paradise

Alan O. Sykes

Article \& Book Review Editors
Kathleen Cully

Robert D. Gilbert

Charles Glick

Mark A. Goldberg

Candice Hoke

Steven Gunby
Rick Levy

David R. Lewis

John Lewis

Rory K. Little

Jonathan E. Richman

Senior Editors

Noel V. Lateef

Editors
Alfred O. Rose

Dieter Snell

Lynn A. Stout

Hector Torres

Monique Witt

John Motulsky

Business Manager: Pamela Standish

Editorial Assistants: Liz Doyle, Gail Kalison

\section{Student Contributors to This Issue}

Randall Kennedy, Interest in Judgments Against the Federal Government: The Need for Full Compensation

Rory K. Little, Protecting Privacy Under the Fourth Amendment

Dieter Snell, Standoff Situations and the Fifth Amendment

Lynn A. Stout, The Case for Mandatory Separate Filing by Married Persons 